\author{
UNIVERSIDADE DE SÃO PAULO \\ FACULDADE DE ZOOTECNIA E ENGENHARIA DE ALIMENTOS
}

CARINE OLIVEIRA DA SILVA

Análise de desempenho microbiológico de uma linha de processamento piloto de caldo de cana 
CARINE OLIVEIRA DA SILVA

\section{Análise de desempenho microbiológico de uma linha de processamento piloto de caldo de cana}

(Versão corrigida)

Dissertação apresentada à Faculdade de Zootecnia e Engenharia de Alimentos da Universidade de São Paulo, como parte dos requisitos para a obtenção do Título de Mestre em Engenharia de Alimentos.

Área de Concentração: Ciências da Engenharia de Alimentos

Orientador: Prof. Dr. Rodrigo Rodrigues Petrus 
Dados Internacionais de Catalogação na Publicação

Serviço de Biblioteca e Informação da Faculdade de Zootecnia e Engenharia de Alimentos da Universidade de São Paulo

Silva, Carine Oliveira da

S586a Análise de desempenho microbiológico de uma linha de processamento piloto de caldo de cana / Carine Oliveira da Silva. -- Pirassununga, 2015.

$78 \mathrm{f}$.

Dissertação (Mestrado) -- Faculdade de Zootecnia e

Engenharia de Alimentos - Universidade de São Paulo. Departamento de Engenharia de Alimentos.

Área de Concentração: Ciências da Engenharia de Alimentos.

Orientador: Prof. Dr. Rodrigo Rodrigues Petrus.

1. Caldo de cana 2. Processamento 3. Pontos críticos de controle 4. Envase asséptico. I. Título. 


\section{DEDICATÓRIA}

Aos meus pais, Antonio e Izabel, pelo incentivo para aprimorar meus conhecimentos e todo apoio necessário.

Ao meu noivo Bruno pelo amor, carinho, compreensão e principalmente pela paciência durante a execução dos testes.

À minha irmã Fulviana pelo apoio e exemplo para realizar o mestrado. 


\section{AGRADECIMENTOS}

Ao Prof. Dr. Rodrigo Rodrigues Petrus, que me acompanha desde a graduação e aceitou ser meu orientador, ensinando-me com paciência e dedicação.

À Profa. Dra. Marta Mitsui Kushida por colaborar para a realização desta pesquisa.

À Faculdade de Zootecnia e Engenharia de Alimentos, pela oportunidade de cursar o mestrado.

À CAPES pelo apoio financeiro por meio da concessão de bolsa de mestrado.

Às empresas doadoras da matéria-prima e dos materiais de consumo para a realização da pesquisa, tais como: Tecnocana Tecnologia em cana Ltda, Thech Desinfecção, Merse ${ }^{\circledR}$, usina Abengoa, Hidroazul ${ }^{\circledR}$, Dominusquímica ${ }^{\circledR}$, Genco $^{\circledR}$,

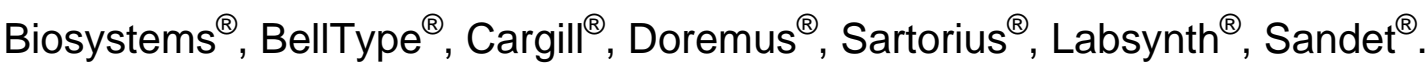

Aos técnicos Fábio e Marcelo e aluna Laura pelo acompanhamento nos testes. 
"Algo só é impossível até que alguém duvide e resolva provar ao contrário"

(Albert Einstein) 


\section{RESUMO}

SILVA, C. O. Análise de desempenho microbiológico de uma linha de processamento piloto de caldo de cana. 2015. 78 f. Dissertação (Mestrado) Faculdade de Zootecnia e Engenharia de Alimentos, Universidade de São Paulo, Pirassununga, 2015.

O presente estudo foi desenvolvido com o objetivo de avaliar o desempenho microbiológico de uma linha de processamento e envase asséptico de caldo de cana acidificado. Para este fim foram identificados pontos críticos de controle em uma planta piloto instalada no Departamento de Engenharia de Alimentos da Faculdade de Zootecnia e Engenharia de Alimentos da Universidade de São Paulo, no campus de Pirassununga/SP. Inicialmente o caldo de cana foi extraído e acidificado com ácido cítrico a um valor de $\mathrm{pH}$ equivalente a 4,3. A bebida acidificada foi pasteurizada a $95^{\circ} \mathrm{C} / 30 \mathrm{~s}$, resfriada a $10^{\circ} \mathrm{C}$ e acondicionada assepticamente em garrafas plásticas seladas por indução. $O$ envase do produto foi conduzido em uma cabina de fluxo de ar unidirecional ISO classe 5 . As garrafas foram descontaminadas por aspersão de ácido peracético a $0,05 \%(\mathrm{v} / \mathrm{v})$, por $20 \mathrm{~s}$ a $45 \stackrel{\circ}{\circ}$. Os selos e as tampas foram esterilizados a $121^{\circ} \mathrm{C} / 15 \mathrm{~min}$. Realizaram-se três processamentos de caldo de cana, em datas distintas, tendo sido caracterizada a matéria-prima e avaliados a qualidade microbiológica do caldo recém-extraído; a água de enxágue final da linha de processamento e envase, após a sua desinfecção com solução de ácido peracético $(0,1 \% \mathrm{v} / \mathrm{v})$ a $50 \stackrel{\circ}{\circ}$ durante $40 \mathrm{~min}$; a embalagem e o produto final. Testes de escala hedônica de 7 pontos foram aplicados para avaliar a aparência, o aroma e o sabor da bebida processada. Os valores médios de $\mathrm{pH}$, de acidez titulável e de sólidos solúveis determinados na matéria-prima foram equivalentes a 5,1; $0,061 \%(\mathrm{~m} / \mathrm{v})$ e $22,3{ }^{\circ}$ Brix, respectivamente. As médias das contagens de microorganismos mesófilos aeróbios totais e de bolores e leveduras no caldo in natura foram equivalentes a $(6,26$ e 5,20$) \log \mathrm{UFC} / \mathrm{mL}$, respectivamente. As médias das contagens na água de enxágue final (pasteurizada) da linha de processamento e envase foram inferiores a $1 \mathrm{UFC} / \mathrm{mL}$. As contagens de mesófilos, de bolores e leveduras nas embalagens foram igualmente inferiores a $1 \mathrm{UFC/embalagem.} \mathrm{As}$ médias das contagens de mesófilos aeróbios e de bolores e leveduras na bebida acidificada e pasteurizada foram equivalentes a $(2,63$ e $<1) \log U F C / m L$, respectivamente. As médias de notas obtidas nos testes de escala hedônica de 7 pontos variaram entre 5,8 e 6,1; demonstrando a elevada aceitação do caldo de cana acidificado. Concluiu-se que a planta de processamento avaliada mostrou-se apta ao processamento de caldo de cana acidificado, estocado sob refrigeração.

Palavras-chave: caldo de cana, processamento, pontos críticos de controle, envase asséptico. 


\begin{abstract}
SILVA, C. O. Sugarcane juice processed in a pilot plant: the microbiological evaluation. 2015. 78 f. M. Sc. Dissertation - Faculdade de Zootecnia e Engenharia de Alimentos, Universidade de São Paulo, Pirassununga, 2015.
\end{abstract}

This study was carried out to evaluate the microbiological performance of a pilot plant designed for acidified sugarcane juice processing. For this purpose, critical control points in a pilot plant were identified. The juice was extracted in a stainless steel electric cylinder mill and then acidified with citric acid until attaining the $\mathrm{pH}$ of 4.3. Next, it was pasteurized in a plate heat exchanger at $95{ }^{\circ} \mathrm{C} / 30 \mathrm{~s}$ and then cooled to $10 \stackrel{\circ}{\circ}$ before being filled into a plastic bottle and induction sealed. Product's filling was performed in an ISO class 5 unidirectional air-flow cabin. Bottles were decontaminated by $0.05 \%$ peracetic acid (PAA) spray, at $45{ }^{\circ} \mathrm{C}$ for $20 \mathrm{~s}$. Seals and caps were sterilized at $121^{\circ} \mathrm{C} / 15 \mathrm{~min}$. Three batches of acidified sugarcane juice were carried out. The qualities of the raw material, rinse water of the processing and filling line (after sanitation with $0.1 \%$ PAA at $50{ }^{\circ} \mathrm{C}$ for $40 \mathrm{~min}$ ), packaging and end product, were all microbiologically evaluated. Seven-point hedonic scale tests were used to evaluate the sensory acceptance of the product. The mean values of $\mathrm{pH}$, titratable acidity and soluble solids content determined in raw sugarcane juice were $5.1,0.061 \%(\mathrm{w} / \mathrm{w})$ and $22.3{ }^{\circ} \mathrm{C}$, respectively. The total aerobic mesophilic and the molds and yeasts mean counts in natural fresh sugarcane juice were (6.26 and 5.20) $\log \mathrm{CFU} / \mathrm{mL}$, respectively. The mesophilic and the molds and yeasts mean counts taken, in both rinse water samples of the processing line and the bottles, were lower than $1 \log \mathrm{CFU} / \mathrm{mL}$. The mesophilic and the molds and yeasts mean counts in acidified and pasteurized sugarcane juice were (2.63 and lower than 1) $\log C F U / m L$, respectively. A beverage with a high sensory acceptance with average scores ranging from 5.8 to 6.1 was achieved. The findings indicated that the procedures that were evaluated met standards for acidified sugarcane juice to be produced then stored under refrigeration.

Keywords: sugarcane juice, processing, critical control points, aseptic filling. 


\section{LISTA DE FIGURAS}

Figura 1 - Estruturas químicas, em sequência, dos princípios ativos dos detergentes (hidróxido de sódio e ácido nítrico) e do sanificante (ácido peracético) utilizados ...... 8 Figura 2 - Planta baixa e layout da linha de processamento desenvolvida para caldo de cana. 16

Figura 3 - Verificação da concentração de ácido peracético (APA) na solução utilizada para a descontaminação das garrafas. 19

Figura 4 - Árvore decisória para identificação de Pontos Críticos de Controle (PCC).

Figura 5 - Imagens da planta piloto utilizada no processamento de caldo de cana. 22

Figura 6 - Fluxograma de produção experimental de caldo de cana. .23

Figura 7 - Ficha para avaliação sensorial de caldo cana acidificado e pasteurizado.

Figura 8 - Esquema ilustrativo dos pontos em que foram coletadas amostras de água de enxágue da linha de processamento e envase. 36

Figura 9 - Tubos de ensaio com caldo ácido (CA), extrato de malte (EM) e Man, Rogosa e Sharp (MRS) e amostra.

Figura 10 - Recipientes contendo ágar thermoacidurans (TAA), ágar all purpose tween (APT) e ágar batata dextrose acidificado com cloranfenicol (PDA-c), respectivamente. 48

Figura 11 - Resultados do teste de esterilidade comercial em (a) ágar thermoacidurans (TAA) anaerobiose, (b) ágar thermoacidurans (TAA) aerobiose, (c) ágar batata dextrose acidificado com cloranfenicol (PDA-C) e (d) ágar all purpose tween (APT). 49

Figura 12 - Intenção de compra dos lotes de caldo de cana acidificado $(\mathrm{pH} 4,3)$ e pasteurizado em relação a porcentagem de provadores, nos três processamentos realizados 


\section{LISTA DE TABELAS}

Tabela 1 - Vantagens e limitações do sistema CIP.

Tabela 2 - Massa de matéria-prima (MP) processada, volume do caldo de cana extraído e número de embalagens produzidas.

Tabela 3 - Identificação e análise dos pontos críticos de controle (PCC) em uma linha piloto de processamento de caldo de cana acidificado

Tabela 4 - Valores médios de pH, sólidos solúveis e acidez titulável no caldo de cana recém-extraído

Tabela 5 - Valores médios obtidos na contagem microbiana em amostras da água de enxágue da linha de processamento após a higienização.

Tabela 6 - Valores médios obtidos na contagem de mesófilos aeróbios totais para amostras de água coletadas da torneira e da mangueira utilizadas na planta piloto.38 Tabela 7 - Contagens (UFC/100 mL) de mesófilos e bolores e leveduras na água de enxágue final da linha de processamento e no envase.

Tabela 8 - Contagens microbianas antes e após a descontaminação das garrafas de PET utilizadas no envase de caldo de cana processado.

Tabela 9 - Contagens microbianas antes e após a esterilização do conjunto de tampas e selos

Tabela 10 - Comparação entre as contagens médias de mesófilos aeróbios encontrados no caldo in natura e no caldo acidificado $(p \approx 4,3)$ e pasteurizado

Tabela 11 - Comparação entre as contagens médias de bolores e leveduras encontrados no caldo in natura e no caldo acidificado $(p \approx 4,3)$ e pasteurizado 45 Tabela 12 - Valor médio de $\mathrm{pH}$ e desvio-padrão referente ao produto estocado por 10 dias a $0^{\circ} \mathrm{C}, 25^{\circ} \mathrm{C}$ a temperatura ambiente $\left(T_{\text {amb. }}\right)$ nos três processamentos ( $P 1$, P2 e P3).

Tabela 13 - Avaliação das amostras de caldo de cana estocadas a $25{ }^{\circ} \mathrm{C}$ e à temperatura ambiente

Tabela 14 - Médias das notas obtidas nos testes de escala hedônica de sete pontos para os lotes de caldo de cana acidificado $(\mathrm{pH} 4,3)$ e pasteurizado. 50 Tabela 15 - Médias das notas atribuídas pelos provadores no julgamento dos descritores estabelecidos para avaliação sensorial de caldo de cana acidificado pasteurizado. 


\section{SUMÁRIO}

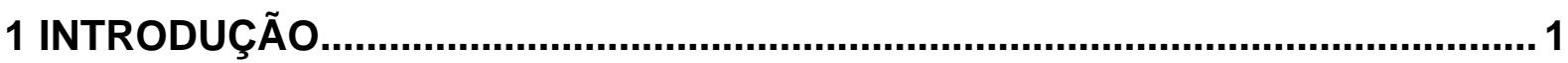

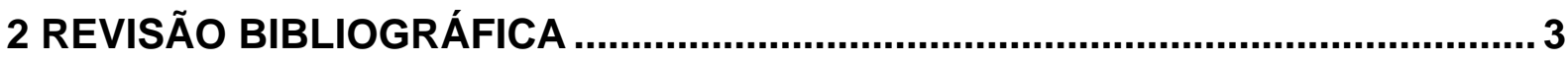

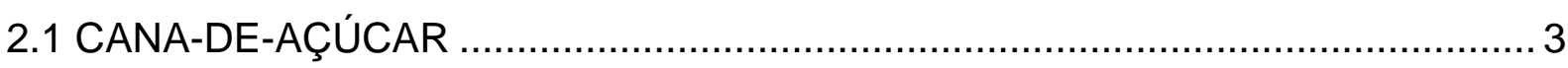

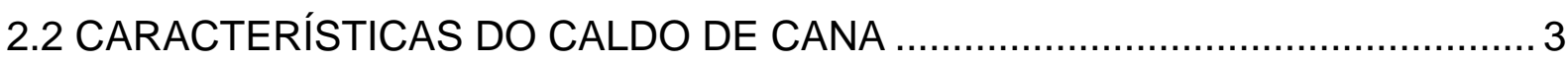

2.2.1 Contaminantes microbiológicos em caldo de cana ........................................ 3

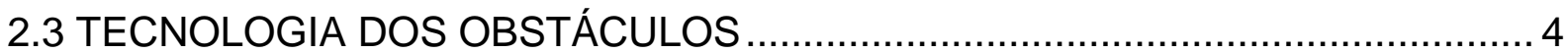

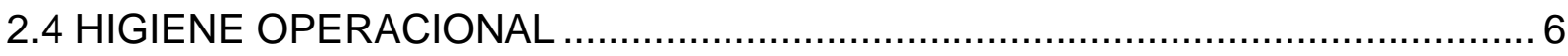

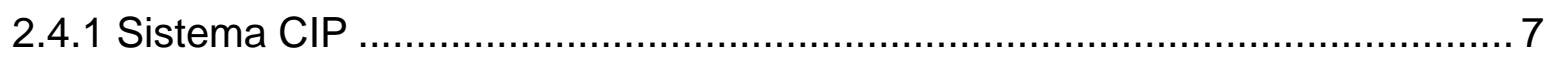

2.5 PONTO DE CONTROLE (PC) E PONTO CRÍTICO DE CONTROLE (PCC)........ 9

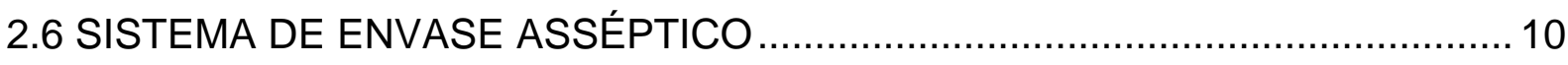

2.7 SISTEMAS DE EMBALAGEM PARA CALDO DE CANA ............................... 10

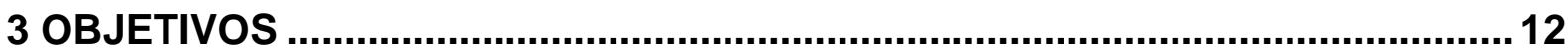

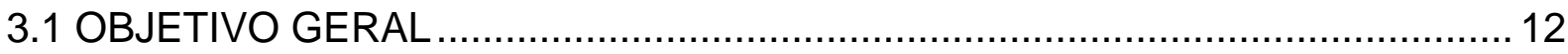

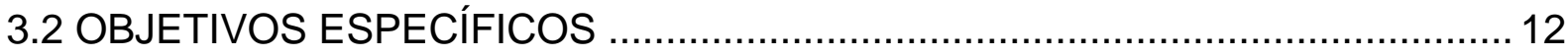

4 MATERIAL E MÉTODOS

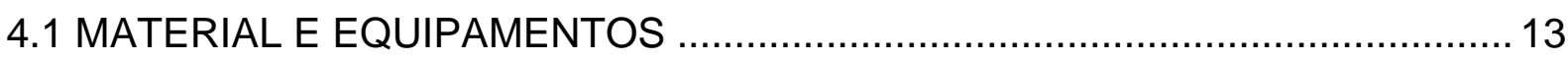

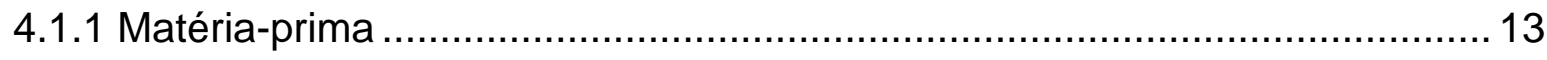

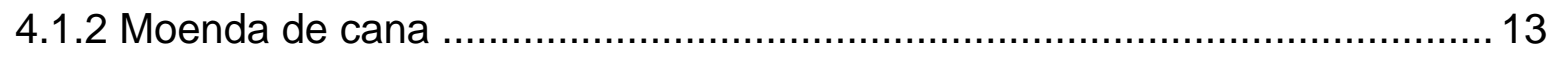

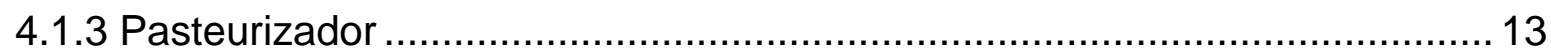

4.1.4 Sistema de envase asséptico ........................................................... 14

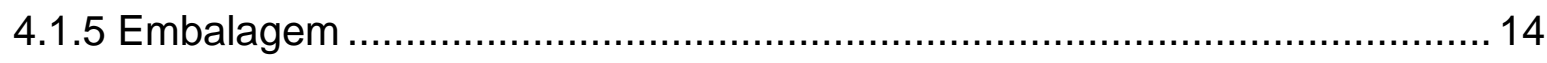

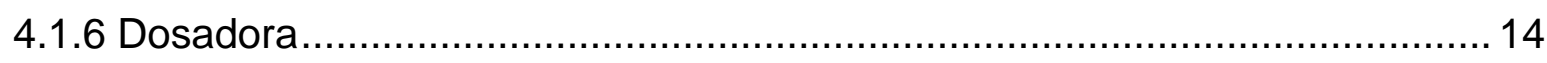

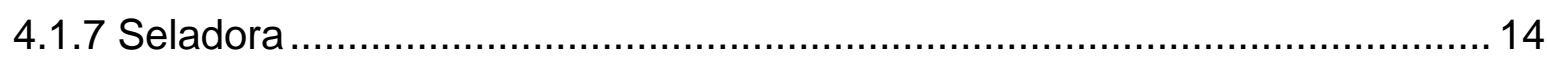

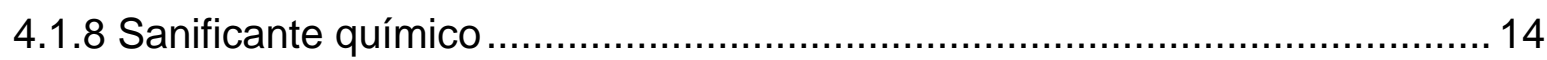

4.1.9 Sistema de descontaminação de garrafas ............................................... 15

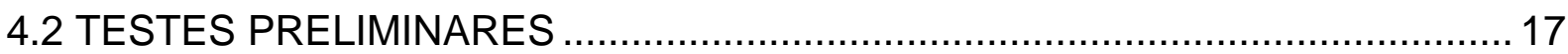

4.2.1 Análise preliminar da água de enxágue da linha de processamento e envase

4.2.2 Análise bacteriológica da água utilizada na planta piloto............................17

4.2.3 Enumeração de micro-organismos na superfície interna da câmara de

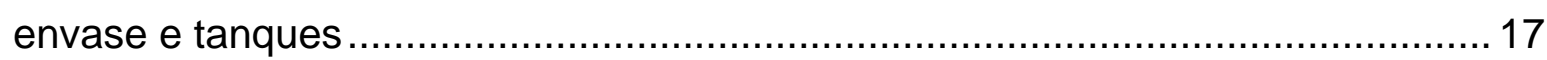

4.2.4 Contagem de micro-organismos em suspensão no ar .............................. 18 
4.2.5 Análise microbiológica preliminar das embalagens .................................. 18

4.3 DESCRIÇÃO E CARACTERIZAÇÃO DO PROCESSAMENTO ….......................20

4.3.1 Higienização da linha de processamento e envase .................................... 24

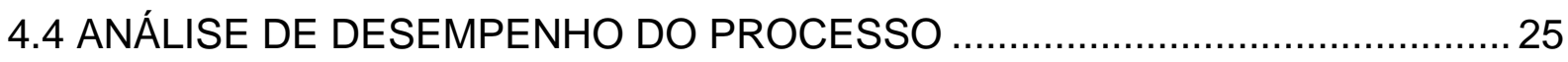

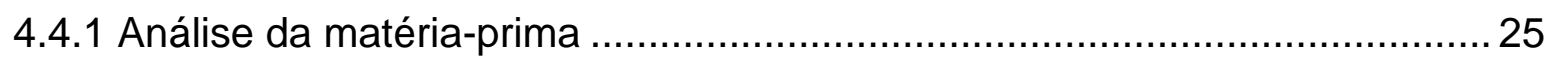

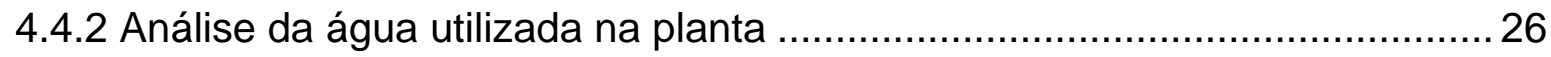

4.4.3 Análise microbiológica das embalagens ..................................................... 26

4.4.4 Avaliação microbiológica do produto final ............................................... 27

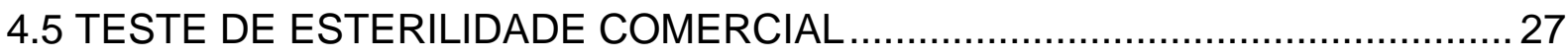

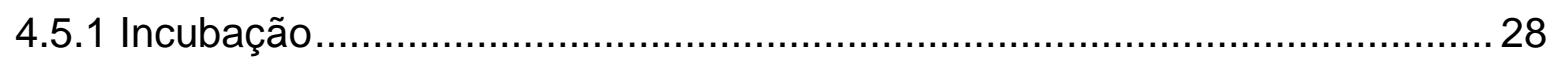

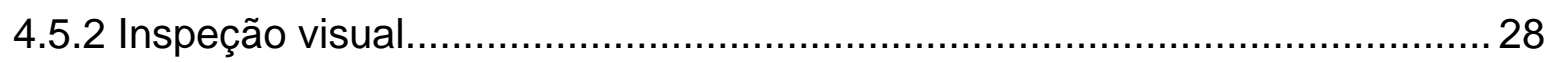

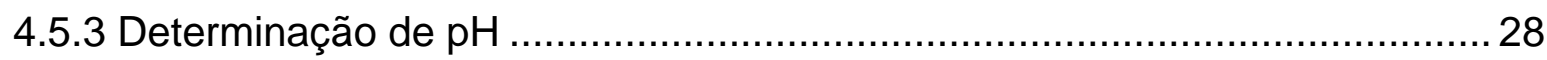

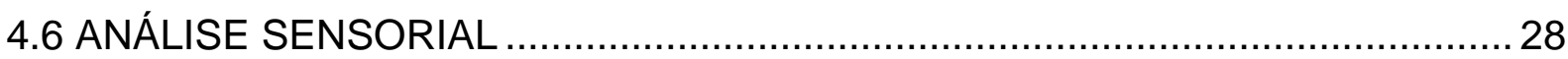

4.6.1 Teste de aceitação do caldo de cana processado ..................................... 28

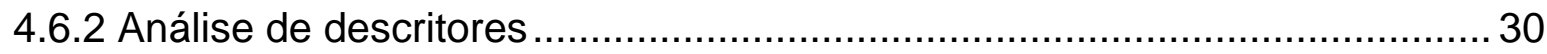

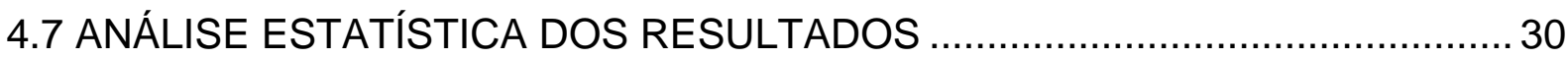

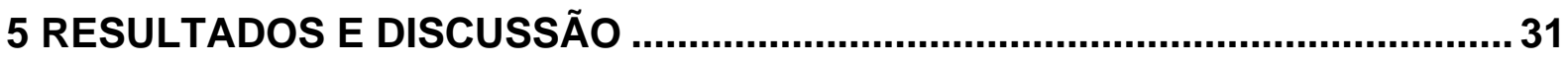

5.1 IDENTIFICAÇÃO DOS PONTOS CRÍTICOS DE CONTROLE (PCC) ................. 31

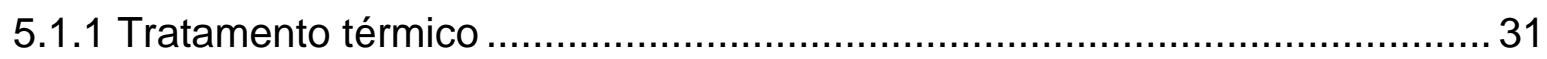

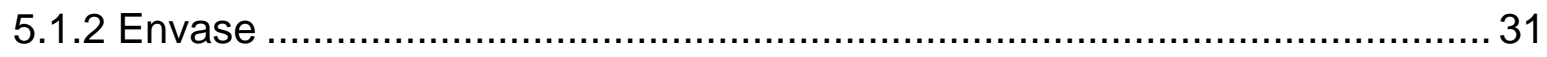

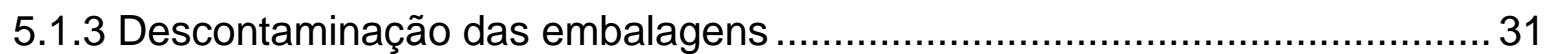

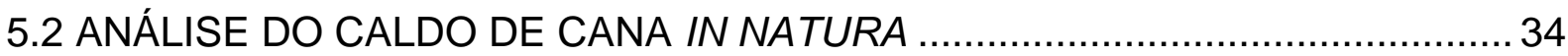

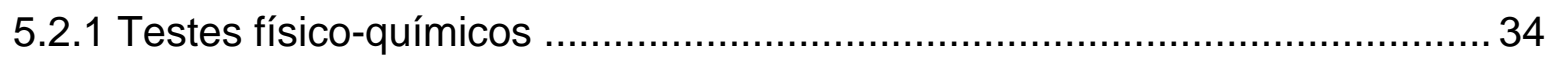

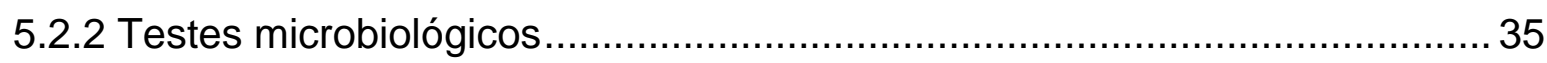

5.3 TESTES QUE ANTECEDERAM AOS PROCESSAMENTOS …........................ 35

5.3.1 Análise preliminar da água de enxágue da linha de processamento e envase 35

5.3.2 Análise bacteriológica preliminar da água utilizada na planta de

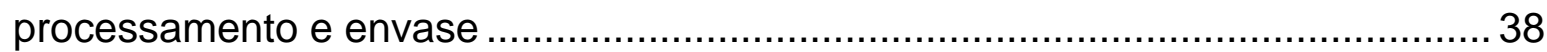

5.3.3 Superfície interna da câmara de envase e tanques..................................... 39

5.3.4 Ar da planta de processamento e na câmara de envase ............................... 39

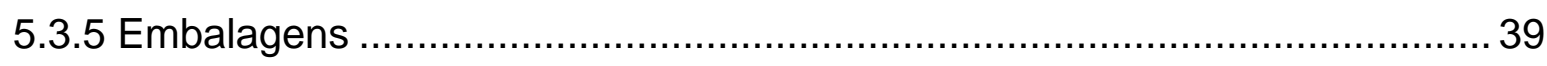

5.4 ANÁLISES DE DESEMPENHO DOS PROCESSAMENTOS ............................. 40

5.4.1 Avaliação da qualidade microbiológica do caldo de cana in natura.............. 40 
5.4.2 Análise microbiológica da água de enxágue final da linha de processamento e envase.

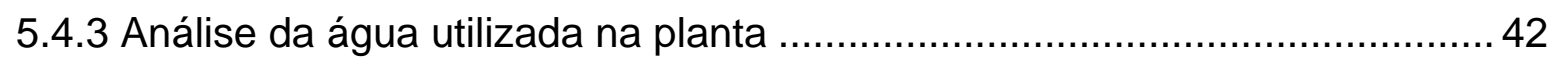

5.4.4 Análise microbiológica das embalagens ............................................... 42

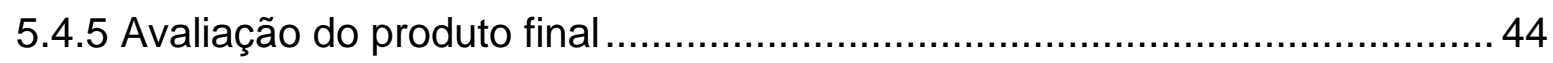

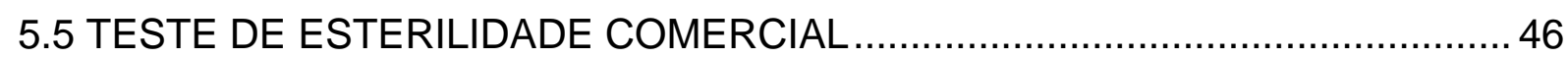

5.5.1 Inspeção visual das amostras ................................................................... 46

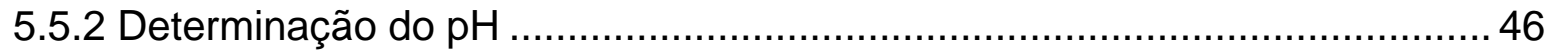

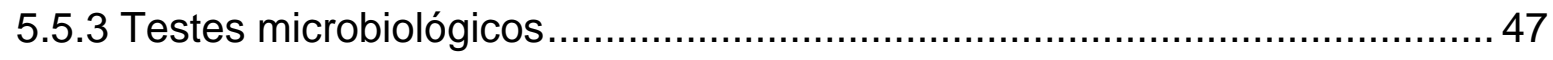

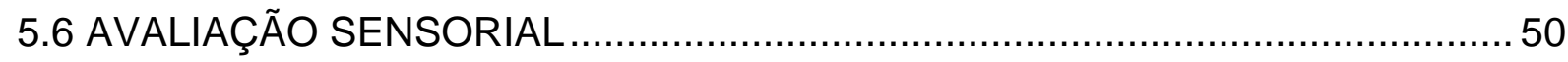

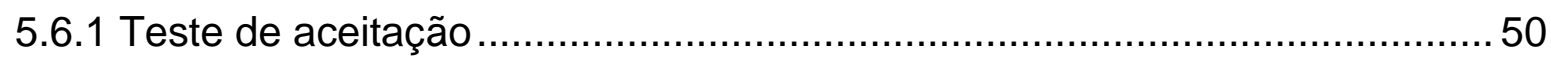

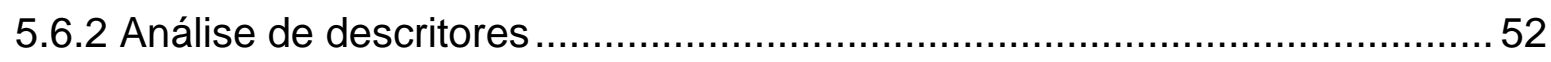

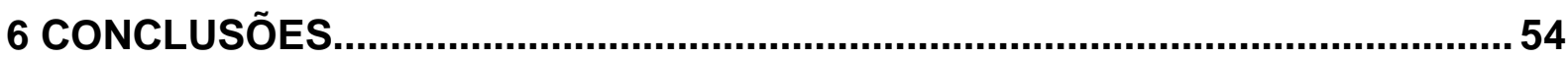

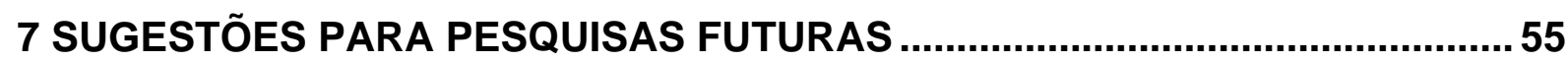

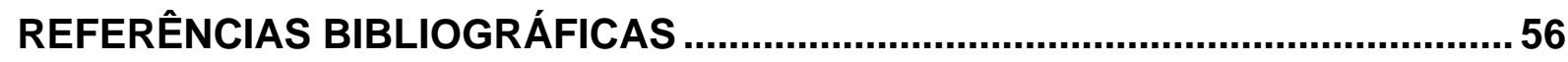

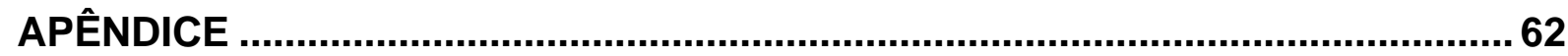

APÊNDICE A - FICHA PARA INSPEÇÃO DAS AMOSTRAS E ANÁLISE DE

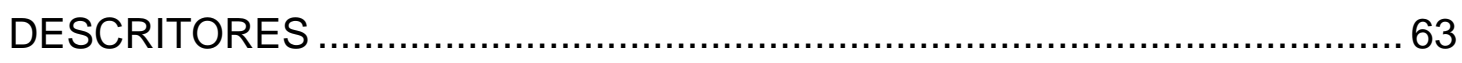

APÊNDICE B - RESULTADOS DOS TESTES PRELIMINARES PARA ANÁLISES MICROBIOLÓGICAS DAS EMBALAGENS ................................6 65 APÊNDICE C - RESULTADOS DOS PROCESSAMENTOS REALIZADOS PARA ANÁLISES MICROBIOLÓGICAS DAS EMBALAGENS .......................66 


\section{INTRODUÇÃO}

A exigência acerca da produção de alimentos seguros, de alta qualidade, com características sensoriais e nutricionais similares à matéria-prima e vida útil estendida é crescente no mercado nacional.

Entretanto, alguns produtos como o caldo de cana, largamente consumido no mercado informal, é frequentemente comercializado em precárias condições higiênico-sanitárias, representando uma ameaça à saúde dos consumidores; a exemplo do incidente ocorrido no ano de 2005, no estado de Santa Catarina, relacionado à ingestão de caldo de cana contaminado por Trypanossoma cruzi, agente etiológico da doença de Chagas.

O caldo de cana é uma bebida de baixa acidez e elevada atividade de água, constituído de, aproximadamente, $80 \%$ de água e $20 \%$ de sólidos totais dissolvidos. Dentre os sólidos destacam-se a sacarose $(17 \%)$, a glicose $(0,4 \%)$ e a frutose $(0,2 \%)$; além de substâncias nitrogenadas, ácidos orgânicos e minerais como ferro, cálcio, potássio, sódio e magnésio (CARVALHO; MAGALHÃES, 2007; STUPIELLO, 1987).

Os micro-organismos deteriorantes do caldo de cana são os principais responsáveis pela alteração do produto ocasionando a degradação química, física e sensorial da bebida. A deterioração microbiológica pode ser acelerada se as condições de estocagem forem abusivas, ocorrendo variações significativas na acidez titulável e no pH pela ação de bactérias, bolores e leveduras que transformam açúcares em ácidos e gomas (SILVA; CESAR; SILVA, 2003; YUSOF; SHIAN; OSMAN, 2000).

Neste cenário, as vantagens proporcionadas pela aplicação racional de tecnologias de processamento para caldo de cana relacionam-se à obtenção de uma bebida segura e de elevada qualidade, em qualquer época do ano, independente do período de safra; ao aumento da vida útil e extensão do consumo a locais distantes da região de plantio, com a diminuição do volume de matéria-prima transportada e na diminuição dos custos de transporte.

Neste contexto, a tecnologia dos obstáculos ou dos processos combinados é um conceito de grande importância para o processamento de alimentos. Exemplos de obstáculos que favorecem a estabilização microbiológica do caldo de cana 
incluem a acidificação $(\mathrm{pH}<4,6)$; o tratamento térmico, o envase asséptico em embalagens previamente descontaminadas e a estocagem refrigerada do produto final.

O presente estudo consistiu na monitoração microbiológica de pontos de controle e pontos críticos de controle identificados em uma planta piloto destinada ao processamento de caldo de cana envasado assepticamente em garrafas plásticas. Adicionalmente, implementaram-se procedimentos padronizados de higiene operacional visando à obtenção de uma bebida segura e de elevada qualidade sensorial, estocada sob refrigeração. 


\section{REVISÃO BIBLIOGRÁFICA}

\subsection{CANA-DE-AÇÚCAR}

A cana-de-açúcar é uma gramínea que teve origem no sudeste asiático e é cultivada nas regiões tropicais e subtropicais. Destaca-se pela grande contribuição socioeconômica nacional por meio da expansão por todos os estados brasileiros, principalmente no estado de São Paulo (STUPIELLO, 1987).

A produção e a maturação da cana dependem de diversos fatores interrelacionados que interferem na qualidade e na característica da cana cultivada, tais como: condições do clima e do solo, formas de manejo, cultivar, dentre outros (CÉSAR et al., 1987).

\subsection{CARACTERÍSTICAS DO CALDO DE CANA}

O caldo de cana, conhecido popularmente como garapa, é caracterizado como um líquido opaco, viscoso, com coloração entre pardo e verde escuro e possui composição química variada. Esta diversificação na composição pode ser atribuída à variedade, à sanidade, à idade da cana, às condições climáticas, ao solo, dentre outros (OLIVEIRA et al., 2006).

Por conter nutrientes orgânicos e inorgânicos, alta atividade de água $(0,99)$ e $\mathrm{pH}$ entre 5,0 e 5,5 é um meio bastante favorável para o desenvolvimento de microorganismos deteriorantes e potencialmente patogênicos (GALLO; CANHOS, 1991).

Por ser o Brasil o maior produtor mundial de cana e por ser o caldo de cana bastante apreciado, as agroindústrias existentes e as microempresas do ramo são estimuladas a desenvolver novos produtos e novas tecnologias utilizando a infraestrutura disponível para aumentar a vida útil do alimento e facilitar a sua distribuição comercial (PRATI; MORETTI; CARDELLO, 2005).

\subsubsection{Contaminantes microbiológicos em caldo de cana}

Os micro-organismos são utilizados como indicadores na avaliação da qualidade dos alimentos ou usados nos processamentos, podendo ser classificados 
em: deteriorantes quando ocasionam alterações indesejáveis, patógenos se representam risco à saúde e os micro-organismos benéficos, que modificam as características originais do produto e o transformam em um novo alimento (FRANCO; LANDGRAF, 2008).

Segundo Franco e Landgraf (2008), os sucos extraídos a partir de hortaliças e gramíneas sacarínicas, incluindo o caldo de cana, são menos ácidos comparados aos sucos de frutas. O caldo de cana apresenta micro-organismos provenientes da própria matéria-prima, porém o maior foco de contaminação origina-se de condições inadequadas na produção como armazenamento da matéria-prima, higienização precária de moendas e utensílios, manipulação imprópria, etc. (KITOKO; OLIVEIRA; SILVA, 2004; LOPES; CRESTO; CARRARO, 2007).

$\mathrm{O} \mathrm{pH}$ é um fator de grande importância, pois além de limitar os grupos de micro-organismos capazes de se desenvolver no alimento, influencia no crescimento, na sobrevivência ou na destruição destes (SILVA, 2000).

Deste modo, os produtos com pH igual ou inferior a 4,6; ou acidificados têm a sua estabilização microbiológica consideravelmente favorecida. Micro-organismos deteriorantes presentes no caldo de cana como, por exemplo, os bolores são os principais responsáveis pela alteração do produto estocado, resultando em sensível degradação das características químicas, físicas e sensoriais da bebida.

A redução do $\mathrm{pH}$ do caldo de cana a um valor próximo a 4,0; como proposto neste estudo, restringe a microbiota da bebida a bolores, leveduras, bactérias acidúricas e láticas, que pode ser destruída, em sua maioria, por meio da pasteurização.

\subsection{TECNOLOGIA DOS OBSTÁCULOS}

A vida útil e a segurança dos alimentos são alcançadas por meio do controle de diferentes fatores com intuito de evitar as alterações químicas, físicas ou microbiológicas (GAVA, 1978; SILVA, 2000). Estes fatores são denominados intrínsecos, pois dependem das características próprias do alimento como $\mathrm{pH}$, atividade de água, composição química, etc.; extrínsecos os quais abrangem o ambiente que o alimento se encontra incluindo a umidade e temperatura ambiente, composição química da atmosfera que envolve o alimento, dentre outros; ou 
implícitos que referem-se as propriedades dos próprios organismos, de como respondem ao ambiente e interagem uns com os outros (FRANCO; LANDGRAF, 2008; MOSSEL; GARCÍA; STRUIJK, 2003; SENAI, 2000).

A combinação de dois ou mais fatores mencionados é chamada de obstáculos (Hurdle Technology), denominação atribuída por Leistner em 1980 na Alemanha. Este conceito refere-se aos micro-organismos que, para se desenvolverem, necessitam transpor uma série de barreiras. Com isso, o controle adequado destes fatores atuantes como barreiras impedem o desenvolvimento e/ou a produção de toxinas por micro-organismos capazes de modificar o alimento (JAY, 2005; SENAI, 2000).

Desta forma, a teoria dos obstáculos originou a tecnologia dos obstáculos ou tecnologia de barreiras. Esta tecnologia consiste na junção de técnicas aplicadas de maneira simultânea para a estabilização bioquímica e microbiológica do alimento tornando-o inócuo a saúde do consumidor (CASTRO; COBUCCI; GALERA, 2008; CHIRIFE; FAVETTO, 1992; FRANCO; LANDGRAF, 2008; LEISTNER, 1987; SENAI, 2000).

Como consequência, os métodos tradicionais de conservação de alimentos podem ser aplicados em menor intensidade e em sinergismo para que as modificações nas características do alimento sejam minimizadas (LEVI; GAGEL; JUVEN, 1985; WELTI-CHANES; VERGARA-BALDERAS; LOPEZ-MALO, 2000).

Porém, para as barreiras produzirem efeito, elas devem considerar a população inicial e o tipo de micro-organismo mais provável de ser encontrado no alimento (FELLOWS, 2006). É importante mencionar que a tecnologia dos obstáculos ou dos processos combinados é um conceito amplamente empregado no processamento industrial de alimentos em virtude de importantes vantagens proporcionadas (CHIRIFE; FAVETTO, 1992; LEISTNER; GORRIS, 1995) no que se refere à segurança, à qualidade e ao aumento da vida útil dos alimentos.

Os obstáculos atuantes na estabilização do caldo de cana processado para realização deste estudo incluíram a acidificação, a pasteurização, o envase asséptico da bebida pasteurizada em embalagens previamente descontaminadas e a estocagem refrigerada. 


\subsection{HIGIENE OPERACIONAL}

O conceito de higiene surgiu na Grécia Antiga e o termo higiene originou-se do grego "hygieiné" que significa saúde. Todavia, a sua importância foi reconhecida somente no final do século XIX, ao relacionar os micro-organismos como a principal causa de determinadas doenças (LELIEVELD; MOSTERT; HOLAH, 2005).

Este fato motivou os consumidores a serem mais exigentes, aumentou a fiscalização sanitária e a concorrência entre as empresas do mercado interno e externo, incentivando muitas indústrias a investirem mais na área de higienização (LANGSRUD et al., 2003).

Desde então, é crescente o interesse das indústrias pela produção de alimentos com alta qualidade nutricional e sensorial além de ter uma boa condição higiênico-sanitária para não oferecer riscos à saúde do consumidor (ATHAYDE, 1998; LELIEVELD; MOSTERT; HOLAH, 2005).

O processo de higienização consta de duas etapas: a limpeza e a sanificação. $\mathrm{Na}$ limpeza ocorre a remoção de resíduos orgânicos e minerais das superfícies, principalmente proteínas, gorduras e sais minerais com o uso de detergentes específicos (ANDRADE; MACEDO, 1996). Enquanto que a etapa de sanificação tem por objetivo eliminar micro-organismos patogênicos e reduzir o número de microorganismos deteriorantes para atingir uma quantificação aceitável (ANDRADE, 2008).

Assim, a limpeza e a sanificação são etapas complementares, pois embora na limpeza ocorra redução da carga microbiana das superfícies, esta não é suficiente, sendo a sanificação uma etapa indispensável (GIBSON et al., 1999; WALTON et al., 2008).

Contudo, procedimentos inadequados de limpeza de utensílios e de equipamentos ou regiões nas quais são inacessíveis aos processos de limpezas usuais, não removendo por completo a matéria orgânica, constitui uma fonte de alimento e proteção para os micro-organismos que, desta forma, não entram em contato direto com o sanificante aplicado formando os biofilmes (FRANCO; LANDGRAF, 2008; KATHARIOU, 2002; MACEDO, 2000; PARKAR; FLINT; BROOKS, 2003; SPEERS; GILMOUR, 1985). O tempo para formação do biofilme dependerá da eficiência e da frequência da higienização, e por isso a melhor 
maneira de evitar a formação de biofilmes é uma eficiente e eficaz higienização (GIBSON et al., 1999).

Neste contexto, a implementação de procedimentos padronizados de higiene operacional, aliados à identificação e à monitoração sistemática de pontos de controle e pontos críticos do processo em análise são ações imperativas para se obter a devida eficiência higiênico-sanitária.

\subsubsection{Sistema CIP}

O sistema Clean in Place (CIP) atua através da junção da ação química dos agentes de limpeza e sanificação com a ação mecânica realizada pela velocidade e turbulência do fluxo das soluções para remover sujidades e contaminantes. Desta forma, aplica-se em equipamentos de processamento de alimentos os quais não podem ou não precisam ser desmontados.

O procedimento completo de higienização CIP é realizado por meio de uma série de etapas, a considerar: pré-enxágue com água morna, limpeza com solução aquecida de detergente, enxágue intermediário com água a temperatura ambiente, desinfecção, enxágue final com água potável a temperatura ambiente (CRAMER, 2006).

As etapas descritas devem ser efetuadas conforme a sequência mencionada e o sucesso de uma etapa dependerá da completa realização da etapa anterior (OMAFRA, 2015).

É importante enfatizar que na fase de pré-enxágue, temperaturas acima de $40 \stackrel{\circ}{\circ}$ não são recomendadas, pois o calor provoca modificações em sujidades contendo amido e proteína dificultando as etapas posteriores da higienização (LELIEVELD; MOSTERT; HOLAH , 2005).

Uma maneira de certificar se as soluções foram completamente removidas do circuito é por meio da medição do pH. Assim, este parâmetro indica o início de cada fase e o final do enxágue.

As estruturas químicas básicas dos detergentes e sanificantes utilizados neste estudo estão apresentadas na Figura 1. 
Figura 1 - Estruturas químicas, em sequência, dos princípios ativos dos detergentes (hidróxido de sódio e ácido nítrico) e do sanificante (ácido peracético) utilizados.
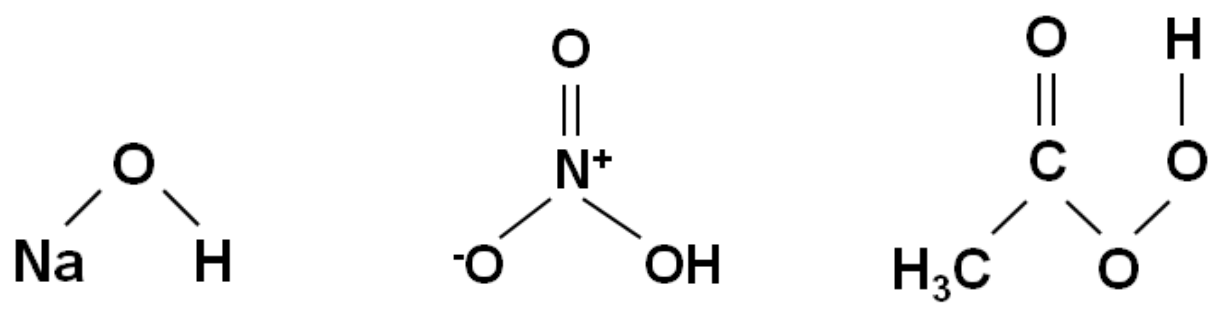

Fonte: SOLOMONS, T. W. G.; FRYHLE, C. B. Química orgânica. Rio de Janeiro: LTC, 2006. 542p.

O APA possui ótimo desempenho por conter propriedades que atuam na destruição de células vegetativas e esporuladas. A utilização do APA possui como vantagens a possibilidade de aplicação em baixas temperaturas e concentrações; biodegradabilidade e baixo efeito residual. Como desvantagens citam-se a produção de vapor irritante a pele e às vias respiratórias, liberação de odores desagradáveis, necessitando de precauções no manuseio, especialmente da solução concentrada; baixa estabilidade da solução de uso (diluída) e incompatibilidade com cobre, ferro e alumínio (FIGUEIREDO, 1999; REUTER, 1988; TOLEDO, 1974).

A maioria das linhas de produção na indústria de bebidas recorrem aos sistemas CIP para a sua higienização por se tratar de processamentos contendo várias tubulações e válvulas (WILDBRETT, 2006).

A eficácia deste sistema irá depender tanto do tipo de sujidade, da aplicação frequente na temperatura e concentração adequada de detergente e sanificante, e da ação mecânica, quanto do design, da construção, da instalação e do modo de funcionamento da linha de processo variando desta maneira o tempo da higienização e o possível risco de contaminação (LELIEVELD; MOSTERT; HOLAH, 2005; SPRENGER, 2005).

Faria (2010) cita as principais vantagens e desvantagens da aplicação do sistema CIP, apresentadas na Tabela 1. 
Tabela 1 - Vantagens e limitações do sistema CIP.

\begin{tabular}{ll}
\hline \multicolumn{1}{c}{ Vantagens } & \multicolumn{1}{c}{ Limitações } \\
\hline Redução da mão-de-obra & $\begin{array}{l}\text { Custos elevados com projeto, } \\
\text { instalação e equipamentos }\end{array}$ \\
\hline Operações controladas com precisão & Maior necessidade de manutenção \\
\hline $\begin{array}{l}\text { Reutilização da água e soluções de } \\
\text { limpeza }\end{array}$ & $\begin{array}{l}\text { Inflexibilidade (atua apenas onde está } \\
\text { instalado) }\end{array}$ \\
\hline
\end{tabular}

Higienização imediata dos

equipamentos (reutilização imediata)

Maior segurança para o operador

Fonte: Adaptado de FARIA, M. S. L. Avaliação dos conceitos e procedimentos de limpeza e desinfecção em estabelecimentos alimentares. 2010. 96f. Dissertação (Mestrado) - Faculdade de Medicina Veterinária, Universidade Técnica de Lisboa, Lisboa, 2010.

\subsection{PONTO DE CONTROLE (PC) E PONTO CRÍTICO DE CONTROLE (PCC)}

A indústria alimentícia dispõe de várias ferramentas para garantir a produção de alimentos seguros, destacando-se o sistema de Análise de Perigos e Pontos Críticos de Controle (APPCC). Este sistema é aplicado para identificar qualquer perigo associado ao alimento podendo ser físico, químico ou microbiológico; parâmetros de controle são estabelecidos a fim de evitar ou diminuir os riscos relacionados.

Entende-se por Ponto de Controle (PC) qualquer etapa ou procedimento do processamento de um alimento em que fatores biológicos, químicos ou físicos podem ser controlados; prioritariamente por programas e procedimentos de prérequisitos, como o programa de Boas Práticas de Fabricação (BPF), Procedimentos Padronizados de Higiene Operacional (PPHO) (CNC/CNI/SEBRAE/ANVISA, 2001; JAY, 2005) e Boas Práticas Agrícolas (BPA).

Ponto Crítico de Controle (PCC) é qualquer ponto, etapa ou procedimento no qual se aplicam medidas de controle para manter um perigo sob controle, com o objetivo de eliminá-lo ou reduzi-lo a um nível aceitável. Uma operação unitária é considerada um PCC quando a etapa subsequente não é capaz de reduzir ou eliminar o risco à saúde do consumidor (PASTER, 2006). 


\subsection{SISTEMA DE ENVASE ASSÉPTICO}

Uma das tecnologias de embalagem para alimentos fluidos (bombeáveis) de maior destaque nas últimas décadas, em escala global, é o sistema de envase asséptico que consiste no acondicionamento em baixas temperaturas do produto comercialmente esterilizado em uma embalagem previamente esterilizada, asséptica e hermeticamente fechada.

O procedimento de descontaminação da embalagem pode ser realizado com a aplicação de calor (ar quente ou vapor saturado), de agentes químicos (ácido peracético, peróxido de hidrogênio, ozônio, compostos clorados, etc.) ou radiação (ultravioleta, infravermelha ou ionizante), ou combinações entre os métodos anteriores (ANSARI; DATTA, 2003; SANDEEP; SIMUNOVIC; SWARTZEL, 2004; VEISSEYRE, 1988).

As principais vantagens do sistema asséptico fundamentam-se na produção de um alimento comercialmente esterilizado com qualidade sensorial e nutricional superiores, pela possibilidade de aplicação de temperaturas mais brandas; controle de processo mais confiável, possibilidade de utilização de embalagens termossensíveis, dentre outras (MCLELLAN; PADILLA-ZAKOUR, 2005).

Por outro lado, uma desvantagem do sistema asséptico inclui o alto custo de implantação sendo o motivo pelo qual algumas empresas optam por outro sistema de processamento e envase (SANDEEP; SIMUNOVIC; SWARTZEL, 2004).

\subsection{SISTEMAS DE EMBALAGEM PARA CALDO DE CANA}

O desenvolvimento de tecnologias que utilizam novos polímeros e processos possibilitou o aumento da diversidade de materiais de embalagens para alimentos, dentre eles o uso de embalagens flexíveis as quais possibilitam a aplicação de tratamento com temperaturas moderadas abaixo de $50{ }^{\circ} \mathrm{C}$ (SARANTÓPOULOS; JESUS JÚNIOR, 2007).

As embalagens termossensíveis acopladas com o sistema asséptico usam os termoplásticos que são leves e podem ser moldados em diversos formatos. Os principais termoplásticos utilizados incluem o polietileno de baixa densidade (PEBD), polietileno de alta densidade (PEAD) e polietileno tereftalato (PET), constituindo 
estes os chamados sistemas de embalagem asséptica de segunda geração (BUCHELI; ROBINSON, 1994).

Estes frascos podem utilizar rótulos opacos ou ser pigmentados na tentativa de impedir a interação do produto com a radiação, aumentando a barreira de proteção. A garrafa de PET é uma opção interessante ao atraente mercado atual porque permite o envase de praticamente qualquer tipo de bebida, incluindo caldo de cana. A garrafa de PET apresenta como vantagens o peso reduzido, e consequentemente a facilidade de manuseio e menor fragilidade.

Os sistemas de embalagem para caldo de cana, dependendo do tempo de vida útil pretendido e da temperatura de estocagem devem atender aos seguintes requisitos de proteção: baixa taxa de permeabilidade ao oxigênio e a radiação, baixa pressão parcial de oxigênio no espaço livre da embalagem e dissolvido no produto a fim de evitar a ocorrência de escurecimento enzimático e a oxidação de vitaminas e pigmentos (ALVES; GARCIA, 1993; BUCHELI; ROBINSON, 1994; GRAUMLICH; MARCY; ADAMS, 1986). 


\section{OBJETIVOS}

\subsection{OBJETIVO GERAL}

O objetivo da pesquisa em questão baseou-se na análise de desempenho microbiológico de uma linha semi-asséptica de processamento e envase, projetada para micro escala de produção de caldo de cana acidificado, estocado sob refrigeração.

\subsection{OBJETIVOS ESPECÍFICOS}

Os objetivos específicos são mencionados a seguir:

1. Identificação de pontos críticos de controle (PCC) em uma linha semi-asséptica para processamento de caldo de cana acidificado.

2. Controle microbiológico do caldo de cana in natura, da água de enxágue final da linha de processamento e envase, das embalagens e do produto final.

3. Implementação de procedimentos padronizados de higiene operacional.

4. Análise da aceitação sensorial do produto final. 


\section{MATERIAL E MÉTODOS}

\subsection{MATERIAL E EQUIPAMENTOS}

A matéria-prima, os principais materiais e equipamentos utilizados na pesquisa estão descritos a seguir.

\subsubsection{Matéria-prima}

A matéria-prima (Saccharum officinarum, cultivar SP 3250) foi fornecida, previamente raspada, pela Tecnocana Tecnologia em Cana Ltda, Santa Cruz das Palmeiras/SP e processada 24 horas, aproximadamente, após a colheita.

\subsubsection{Moenda de cana}

A extração do caldo de cana foi realizada em uma moenda elétrica constituída por cilindros de aço inoxidável, fabricada pela Maqtron, Joaçaba/SC.

\subsubsection{Pasteurizador}

Para pasteurização da bebida utilizou-se um trocador de calor a placas elétrico com vazão nominal de $300 \mathrm{~L} / \mathrm{h}$, equipado com válvula pneumática de retorno de produto não pasteurizado, construído pela Sumá Indústria e Comércio Ltda, Campinas/SP. O trocador de calor é constituído pelas seções de regeneração (produto pasteurizado em contra-corrente com a bebida não pasteurizada), aquecimento (bebida pré-aquecida em contra-corrente com água quente), retenção e resfriamento (produto pasteurizado pré-resfriado em contra-corrente com água gelada). 


\subsubsection{Sistema de envase asséptico}

Uma cabina com fluxo de ar unidirecional horizontal (ISO classe 5) de fabricação Veco do Brasil, Campinas/SP foi utilizada no envase asséptico do produto.

\subsubsection{Embalagem}

O caldo de cana foi acondicionado em garrafas de polietileno tereftalato (PET) pigmentadas na cor branca, com capacidade para $350 \mathrm{~mL}$, com tampas de rosca de polipropileno (PP) e selo de alumínio, adquiridos da Plasvipack Importação e Exportação Ltda, São Paulo/SP.

\subsubsection{Dosadora}

O envase do produto foi conduzido por meio de uma dosadora gravimétrica microprocessada semi-automática de fabricação Polienva-Movitron - São Paulo/SP.

\subsubsection{Seladora}

A aplicação dos selos de alumínio foi realizada por meio de uma termosseladora por indução eletromagnética de fabricação Enercon Industries Corporation, modelo Super Seal Jr.

\subsubsection{Sanificante químico}

O agente Peroxide ${ }^{\circledR} \mathrm{P} 170$, solução aquosa constituída por $17 \%(\mathrm{~m} / \mathrm{v})$ de ácido peracético, fornecido pela Bell Type, Taboão da Serra /SP foi utilizado como sanificante na descontaminação das embalagens e da linha de processamento e envase. 


\subsubsection{Sistema de descontaminação de garrafas}

As garrafas foram descontaminadas por aspersão com solução de ácido peracético $0,05 \%(\mathrm{v} / \mathrm{v})$ a $45{ }^{\circ} \mathrm{C}$ por $20 \mathrm{~s}$. O sistema de aspersão foi adquirido da Casa das Cantinas, Bento Gonçalves/RS. As tampas e os selos de alumínio foram esterilizados a $121^{\circ} \mathrm{C} / 15 \mathrm{~min}$ em autoclave.

A Figura 2 ilustra a planta baixa e o layout da linha de processamento utilizado para o caldo de cana. 
Figura 2 - Planta baixa e layout da linha de processamento desenvolvida para caldo de cana.

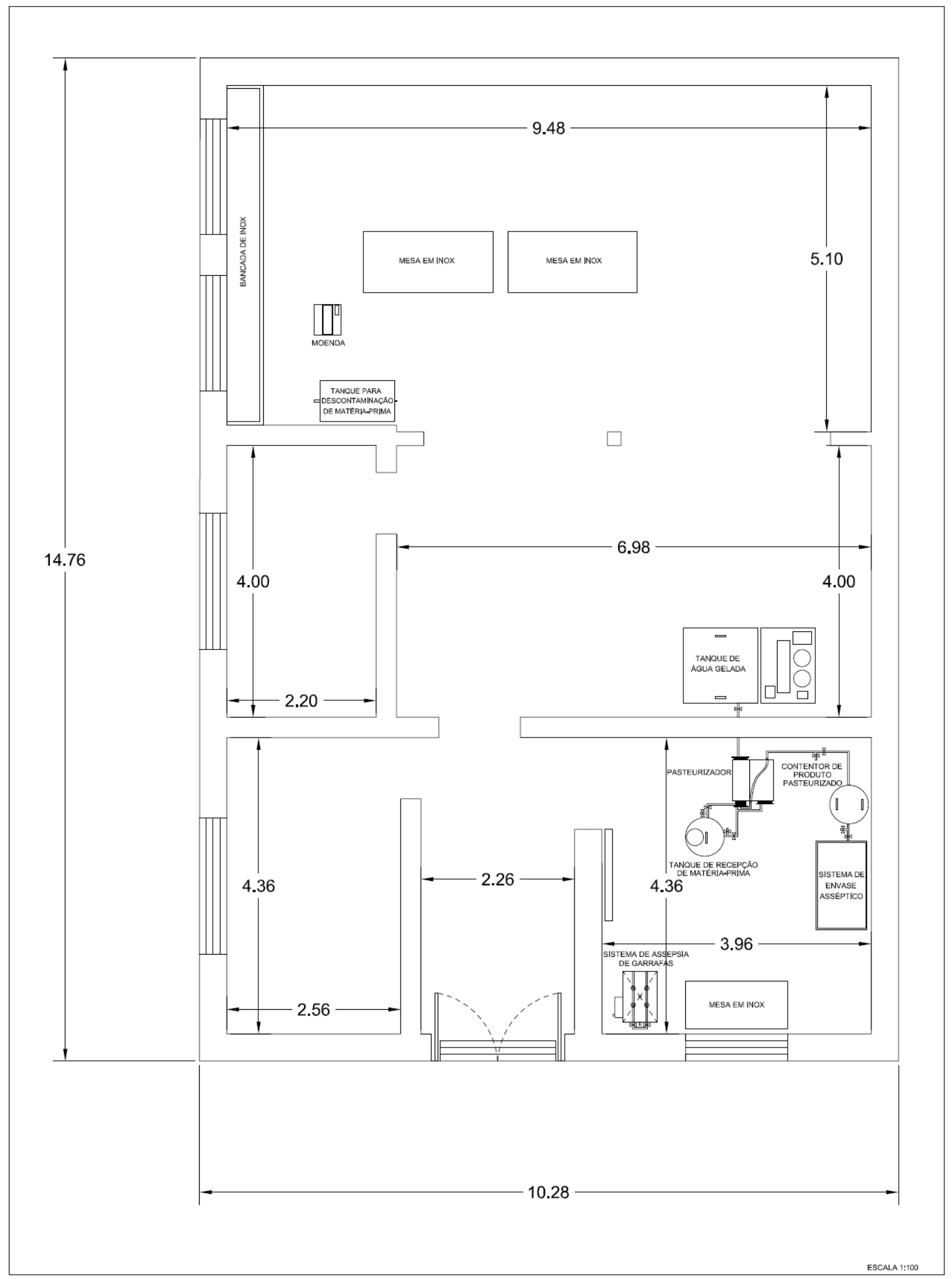

Fonte: Própria autoria. 


\subsection{TESTES PRELIMINARES}

Dois testes preliminares (T1 e T2) antecederam aos três processamentos ( $\mathrm{P} 1$, P2 e P3) para analisar pontos específicos da planta piloto, antes e após o procedimento de higienização, com o intuito de aprimorá-los.

\subsubsection{Análise preliminar da água de enxágue da linha de processamento e envase}

Para as análises microbiológicas da água de enxágue da linha de processamento e envase, antes e após a higienização, coletaram-se $200 \mathrm{~mL}$ de água em diferentes pontos, a saber: a montante e a jusante do pasteurizador, do contentor de produto pasteurizado e da dosadora.

As amostras de água coletadas nos referidos pontos foram transferidas assepticamente para um sistema de filtração à vácuo com membrana de celulose de porosidade $0,45 \mu \mathrm{m}$. Após a filtração as membranas foram transferidas para placas de petri com Ágar Padrão para Contagem (PCA), incubadas a $35^{\circ} \mathrm{C} / 48 \mathrm{~h}$, e Ágar Batata Dextrose adicionado de cloranfenicol (PDA-c), incubadas a $25{ }^{\circ} \mathrm{C} / 96 \mathrm{~h}$. A enumeração das colônias correspondeu às médias de três repetições por ponto avaliado, expressa como UFC/mL de amostra de água.

\subsubsection{Análise bacteriológica da água utilizada na planta piloto}

Três amostras de $200 \mathrm{~mL}$ de água foram retiradas diretamente da torneira e da mangueira utilizada na planta. Procedeu-se à filtração à vácuo, asséptica, em membranas de 0,45 $\mu \mathrm{m}$, transferidas para placas com PCA, seguido de incubação a $35^{\circ} \mathrm{C} / 48 \mathrm{~h}$.

\subsubsection{Enumeração de micro-organismos na superfície interna da câmara de envase e tanques}

Os pontos analisados incluíram a superfície interna da câmara de envase, do tanque de recepção da matéria-prima e do contentor do produto processado. 
A avaliação microbiológica das superfícies de contato antes e após a higienização foi realizada por meio de esfregaço de uma esponja a qual estava contida em uma bolsa plástica estéril e umedecida com $10 \mathrm{~mL}$ água peptonada $0,1 \%$. Durante a coleta utilizou-se um molde estéril para delimitar a área da superfície em $50 \mathrm{~cm}^{2}$. Logo após retornar a esponja na bolsa plástica, adicionou-se $90 \mathrm{~mL}$ de água peptonada e esta foi massageada manualmente por 3 minutos.

Uma alíquota de $0,1 \mathrm{~mL}$ foi transferida para placas com PCA e PDA-c para posterior contagem. Os resultados obtidos constam de 10 pontos coletados com a mesma esponja por ponto avaliado, tendo sido expressos em UFC/cm².

\subsubsection{Contagem de micro-organismos em suspensão no ar}

A avaliação da qualidade microbiológica do ar da planta de processamento e do interior da câmara de envase asséptico foi baseada na técnica de sedimentação. Para este fim, foram expostas placas de petri contendo PCA e PDA-c, durante 30 min, para quantificação de mesófilos aeróbios totais e bolores e leveduras, respectivamente. Os resultados foram expressos em UFC/cm $30 \mathrm{~min}$.

\subsubsection{Análise microbiológica preliminar das embalagens}

As análises microbiológicas das embalagens incluíram garrafas e tampas. Foram realizados dois testes distintos antes dos três processamentos com intuito de definir a melhor combinação dos parâmetros e dos métodos utilizados.

No primeiro teste as garrafas foram separadas aleatoriamente em três lotes com 2 garrafas cada lote. A divisão foi realizada na mesma forma antes e após a descontaminação, por meio da aspersão de solução de APA a 0,05\% (v/v) a $45{ }^{\circ} \mathrm{C}$ por 15 segundos. A concentração de APA na solução foi verificada por meio de fita indicadora (Figura 3). 
Figura 3 - Verificação da concentração de ácido peracético (APA) na solução utilizada para a descontaminação das garrafas.

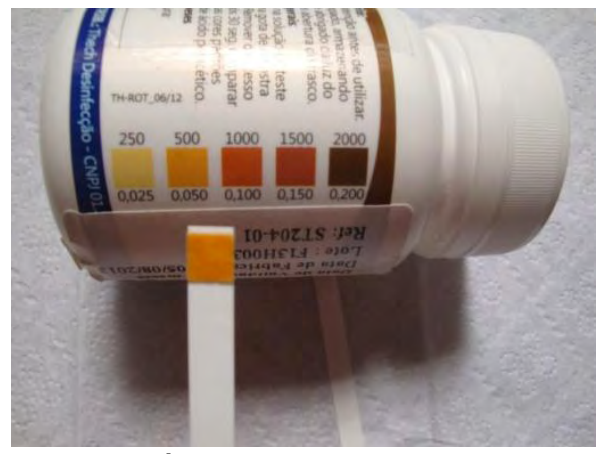

Fonte: Própria autoria

O procedimento adotado na análise microbiológica das garrafas consistiu na adição de $50 \mathrm{~mL}$ de uma solução de enxágue esterilizada no interior das garrafas, contendo $0,94 \%(\mathrm{v} / \mathrm{v})$ de tenso ativo Tween $80,0,50 \%(\mathrm{v} / \mathrm{v})$ de solução de tiossulfato de sódio a $10 \%(\mathrm{~m} / \mathrm{v})$ e $98,56 \%$ de solução de água peptonada $0,1 \%(\mathrm{~m} / \mathrm{v})$. Prosseguiu-se com o fechamento das garrafas e agitação vigorosa e padronizada durante 1 (um) minuto. A solução de enxágue das embalagens foi filtrada à vácuo, conforme descrito anteriormente para a análise da água de enxágue da linha de processamento.

As tampas em conjunto com os selos foram separadas aleatoriamente em 3 (três) lotes com 2 (duas) tampas em cada lote, da mesma maneira antes e após a descontaminação. A descontaminação constituiu na imersão das tampas em solução contendo APA a concentração de $0,05 \%(\mathrm{v} / \mathrm{v})$, a temperatura ambiente por 30 minutos. A avaliação microbiológica foi pela técnica do swab a qual constava na coleta da amostra por meio de um swab umedecido em $1 \mathrm{~mL}$ de água peptonada $0,1 \%$, sendo este transferido para um tubo de ensaio com $9 \mathrm{~mL}$ de água peptonada, prosseguindo com a agitação usando o Vortex por 5 minutos. Alíquotas de $0,1 \mathrm{~mL}$ foram transferidas para placas com PCA e PDA-c, encubadas para posterior contagem e os resultados foram expressos em UFC/ conjunto selo e tampa.

Para o segundo teste dividiu-se em 3 (três) lotes com 6 (seis) garrafas em cada. Adicionou-se $100 \mathrm{~mL}$ da solução esterilizada em cada garrafa seguido de agitação. As análises e a enumeração das placas foram realizadas a cada duas garrafas, sendo assim 3 (três) contagens de cada grupo de micro-organismo avaliado por lote. 
Em seguida a sanificação das garrafas foi alterada com a aspersão de solução de APA na concentração a 0,05\% (v/v) a $45{ }^{\circ} \mathrm{C}$ por 20 segundos e aplicado o método de sistema de filtração à vácuo.

Tampas e selos foram separadas em 3 (três) lotes com 6 (seis) tampas em cada lote, da mesma maneira antes e após a descontaminação em autoclave a $121^{\circ} \mathrm{C}$ por 15 minutos. A análise microbiológica foi feita por meio do método de coleta com swab.

\subsection{DESCRIÇÃO E CARACTERIZAÇÃO DO PROCESSAMENTO}

O processamento iniciou-se com a higienização da cana por imersão em solução de dicloro orgânico $5 \%(\mathrm{~m} / \mathrm{v})$, a $25 \stackrel{\circ}{\circ}$, durante 20 minutos, seguindo-se com a extração do caldo utilizando a moenda elétrica.

Após a filtração, para remoção de resíduos do bagaço, o caldo de cana teve o seu $\mathrm{pH}$ padronizado a um valor equivalente a 4,3. Para este fim, foi adicionado ácido cítrico ao caldo, obtendo-se assim uma bebida acidificada.

O caldo de cana acidificado foi pasteurizado a $95{ }^{\circ} \mathrm{C} / 30 \mathrm{~s}$, resfriado a $10{ }^{\circ} \mathrm{C}$, aproximadamente, e transferido para um contentor isotérmico hermeticamente fechado, no qual permaneceu por um período próximo a $1 \mathrm{~h}$ antes do envase.

Procedeu-se ao envase da bebida pasteurizada no interior da cabina de fluxo de ar unidirecional, de forma a assegurar o envase asséptico do produto. As embalagens foram, finalmente, seladas por indução para garantir a sua hermeticidade.

A identificação dos PCCs da linha de processamento foi norteada pela utilização da "árvore decisória", definida como uma sequência de perguntas objetivas direcionadas a cada perigo identificado. O modelo de árvore decisória adotado está representado pela Figura 4 (TONDO; BARTZ, 2011). 
Figura 4 - Árvore decisória para identificação de Pontos Críticos de Controle (PCC).

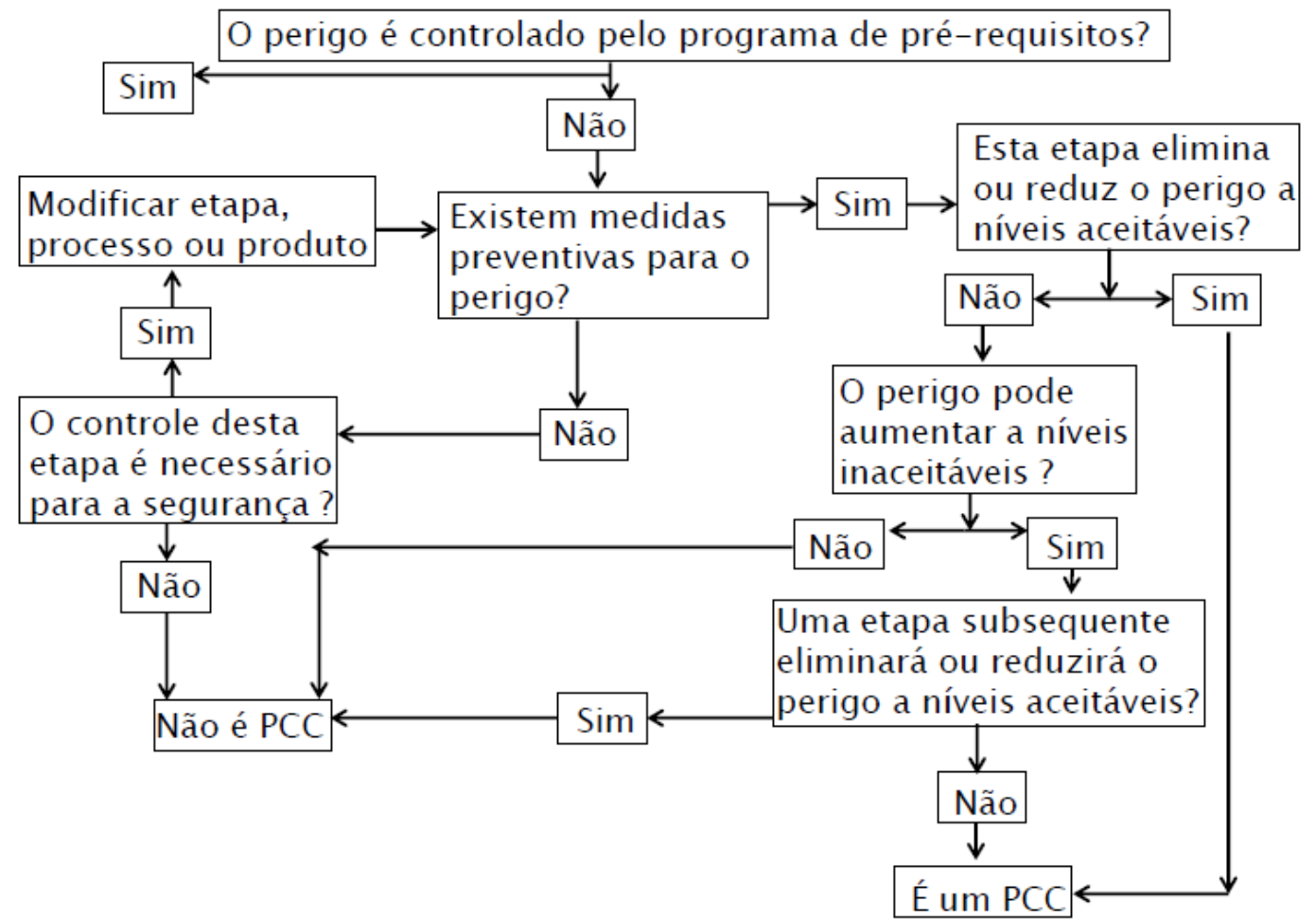

Fonte: GIORDANO, J. C.; GALHARDI, M. G. Análise de perigos e pontos críticos de controle (APPCC). Campinas: SBCTA, 2004. 92p.

A Figura 5 ilustra as etapas realizadas no processamento do caldo de cana. 
Figura 5 - Imagens da planta piloto utilizada no processamento de caldo de cana.

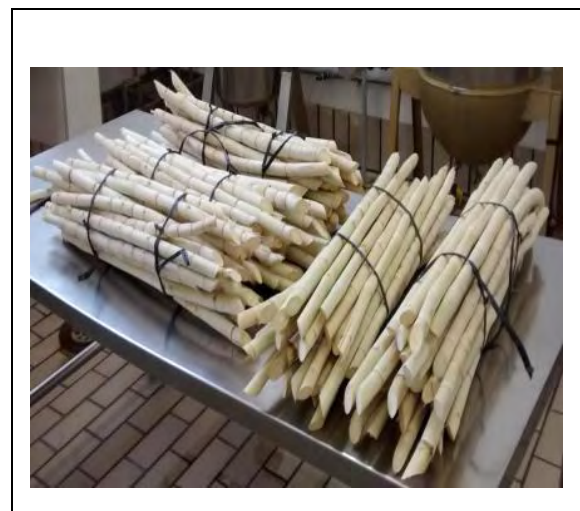

(a) Matéria-prima

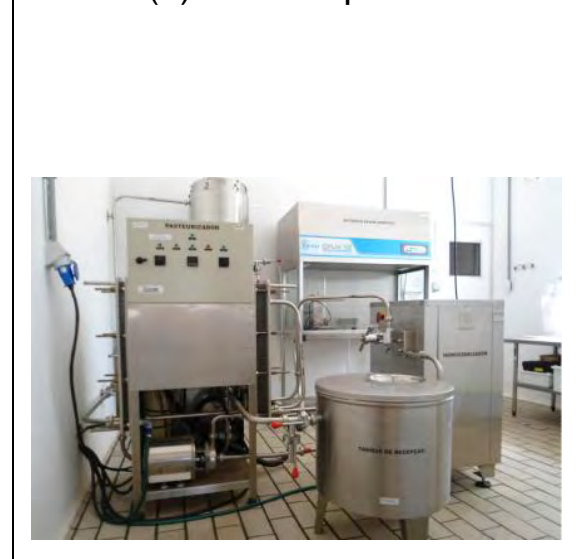

(d) Linha de processamento e envase

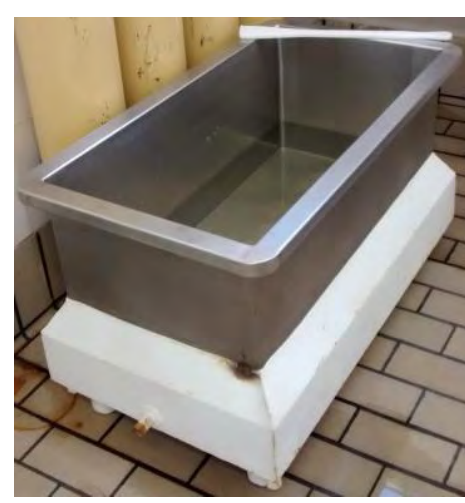

(b) Tanque para descontaminação de matéria-prima

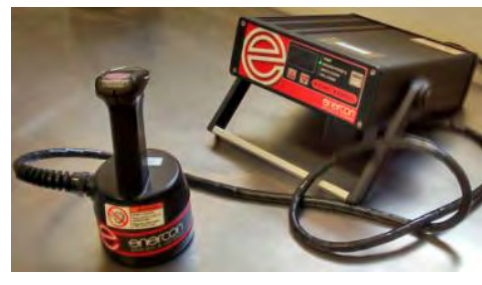

(e) Seladora por indução

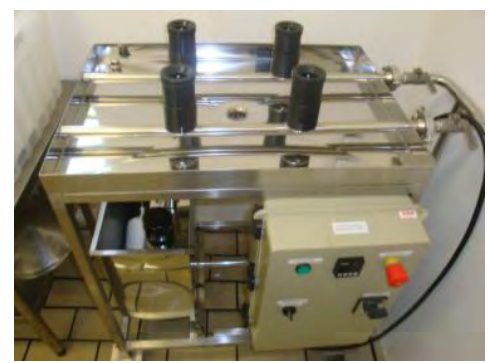

(g) Sistema de assepsia de garrafas

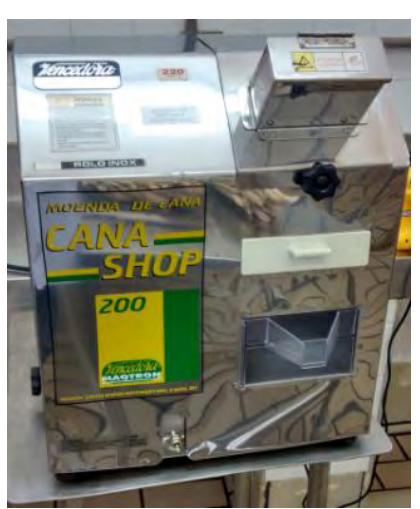

(c) Moenda elétrica

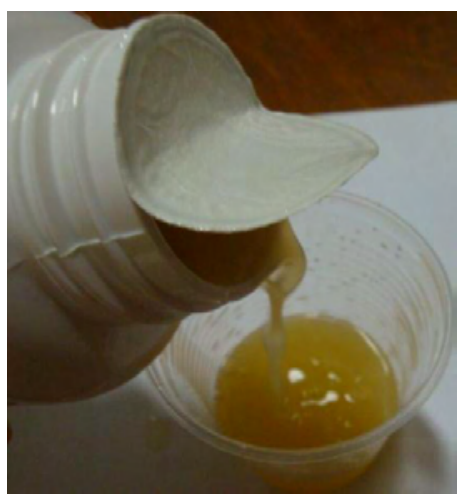

(f) Produto final

Fonte: Própria autoria.

A Figura 6 representa o fluxograma com as etapas executadas no processamento do caldo de cana, tendo sido produzidos três lotes da bebida, em diferentes períodos do ano. As etapas em negrito representam os obstáculos (fatores extrínsecos) atuantes na estabilização da bebida. Os pontos críticos de controle estão identificados como PCC. 
Figura 6 - Fluxograma de produção experimental de caldo de cana.

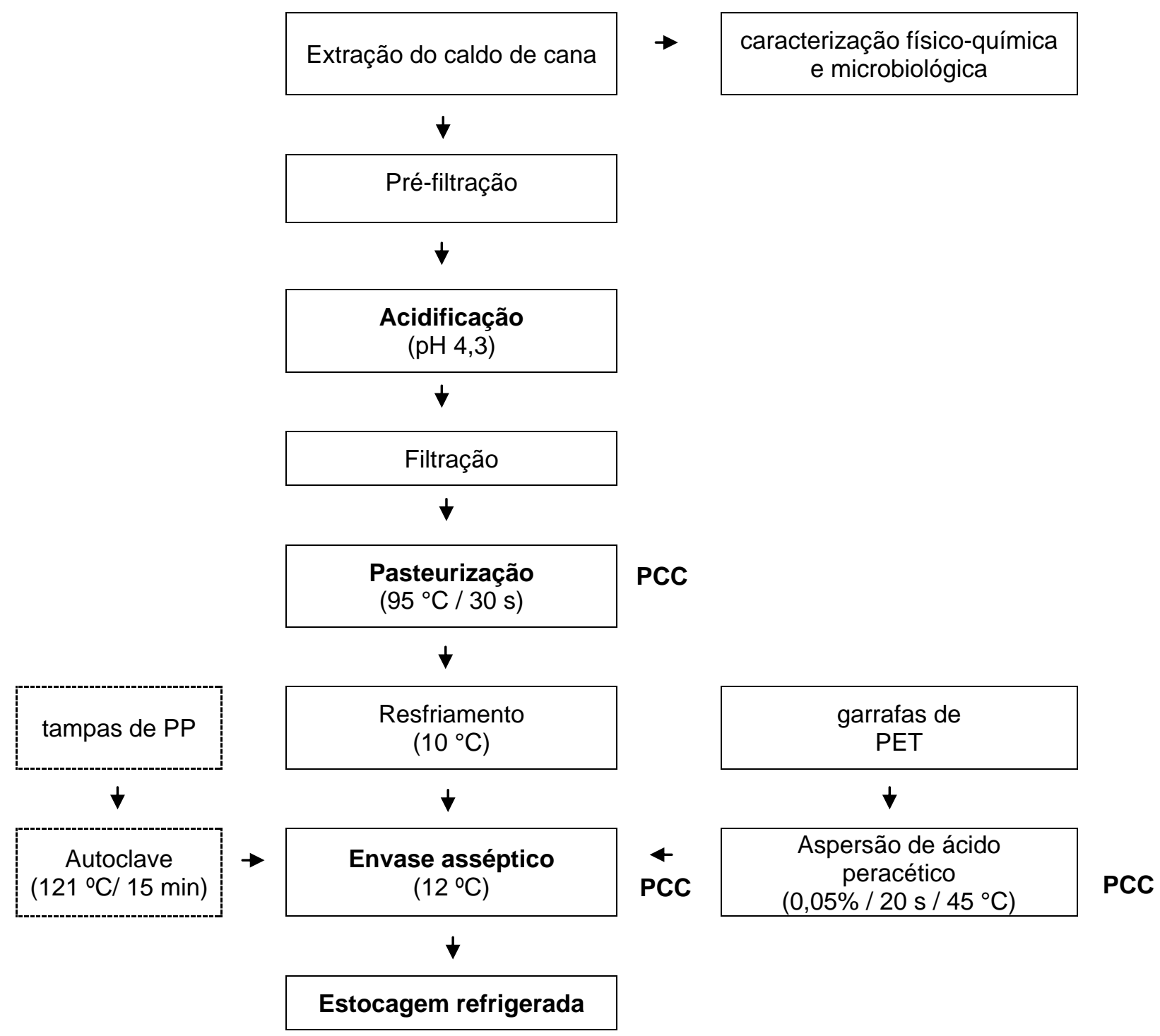

Fonte: Própria autoria.

Os três processamentos realizados diferenciaram-se em relação às massas de matéria-prima processada, ao volume de caldo de cana extraído e ao número de embalagens produzidas, conforme apresentado na Tabela 2. 
Tabela 2 - Massa de matéria-prima (MP) processada, volume do caldo de cana extraído e número de embalagens produzidas.

\begin{tabular}{ccccc}
\hline Lote & $\begin{array}{c}\text { Matéria-prima } \\
(\mathrm{kg})\end{array}$ & $\begin{array}{c}\text { Volume de caldo } \\
\text { extraído (L) }\end{array}$ & $\begin{array}{c}\text { Rendimento } \\
\text { da extração } \\
(\%)\end{array}$ & $\begin{array}{c}\text { Número de } \\
\text { embalagens }\end{array}$ \\
\hline P1 & 82,61 & 41,0 & 50 & 80 \\
P2 & 96,63 & 49,0 & 51 & 107 \\
P3 & 103,10 & 53,5 & 52 & 81 \\
\hline previamente raspada. & & & \\
Fonte: Própria autoria. & & &
\end{tabular}

A Tabela 2 mostra que o valor médio de rendimento obtido na extração do caldo de cana foi de 50\%. Mao, Xu e Que (2007) obtiveram um rendimento de caldo de cana extraído a partir de toletes de cana branqueados próximo a $71 \%$, superior aos valores obtidos no presente estudo. A diferença entre este resultado e aquele do presente estudo pode estar relacionada à variedade de cana utilizada, ao seu estágio de maturação e ao método de extração do caldo. Rendimentos superiores são normalmente obtidos em escala industrial. Por outro lado, Khare et al. (2012) obtiveram um rendimento de $52 \%$, próximo ao valores determinados neste trabalho.

A despeito da variação crescente da massa de matéria-prima processada e do volume de caldo extraído, o número de embalagens produzidas não seguiu a mesma proporção. Este fato deve-se a perdas do volume da bebida, que foram variáveis, durante o processamento e o envase do produto final.

\subsubsection{Higienização da linha de processamento e envase}

A limpeza alcalina da linha de processamento foi realizada com solução de detergente alcalino Sandet ${ }^{\circledR} 874$, contendo $0,0067 \%$ (67 mg/L) de $\mathrm{NaOH}$, a $85 \stackrel{\circ}{\circ} \mathrm{C}$ durante 20 min. Após o enxágue para remoção do resíduo alcalino, procedeu-se à limpeza ácida com uma solução de detergente ácido Sandet ${ }^{\Theta} 162$, contendo 0,0025\% (25 mg/L) de $\mathrm{HNO}_{3}$, a $70 \stackrel{\circ}{\circ} \mathrm{C}$ durante 20 min seguido de enxágue final.

A sanificação foi realizada com solução de ácido peracético Peroxide ${ }^{\circledR}$ P170 na concentração de $0,1 \%(\mathrm{v} / \mathrm{v})$ a temperatura de $50 \stackrel{\circ}{\circ}$, durante 40 min. 


\subsection{ANÁLISE DE DESEMPENHO DO PROCESSO}

As análises microbiológicas de amostras coletadas em diferentes etapas do processo foram executadas de acordo com as metodologias descritas por Silva et al. (2010), compreendendo a avaliação da qualidade microbiológica da matéria-prima, da água utilizada na planta piloto, da água de enxágue final de linha de processamento e envase, a enumeração de contaminantes nas embalagens antes e após o procedimento de descontaminação e análise do produto final.

Contagens de micro-organismos esporulados não foram realizadas porque este grupo não foi alvo das tecnologias de processamento aplicadas neste estudo, uma vez que o caldo de cana foi acidificado $(\mathrm{pH} 4,3)$, pasteurizado e estocado sob refrigeração.

\subsubsection{Análise da matéria-prima}

\subsubsection{Testes físico-químicos}

As determinações do $\mathrm{pH}$, do teor de sólidos solúveis e da acidez titulável do caldo recém-extraído foram feitas em triplicata, no local do processamento.

Para análise do $\mathrm{pH}$ foi utilizado um medidor de $\mathrm{pH}$ da MS Tecnopon, modelo mPA 210 (Piracicaba/SP) com eletrodo de vidro calibrado antes de todas as mensurações em pH 4 e 7.

A mensuração do teor de sólidos solúveis foi pelo refratômetro digital da Reichert AR 200 (Depew, Nova York, Estados Unidos) em $20{ }^{\circ} \mathrm{C} \pm 0,1{ }^{\circ} \mathrm{C}$ e expresso em ${ }^{\circ}$ Brix.

A acidez titulável foi determinada por meio de titulação com solução de hidróxido de sódio $(\mathrm{NaOH})$, $1 \mathrm{~N}$ padronizada com biftalato de potássio. A titulação do caldo de cana recém-extraído foi conduzida até atingir um $\mathrm{pH}$ equivalente 8,1 ; sendo o resultado expresso em g de ácido cítrico/100 mL de caldo de cana. 


\subsubsection{Testes microbiológicos}

Em cada processamento foram coletadas três amostras de caldo de cana após a extração, destinadas à contagem de micro-organismos mesófilos aeróbios totais e bolores e leveduras. As amostras foram transferidas para tubos de ensaio contendo solução de água peptonada $1 \%(\mathrm{v} / \mathrm{v})$ com diferentes diluições variando de $10^{-1}$ a $10^{-3}$ e homogeneizadas durante 1 (um) minuto utilizando o agitador Vortex. Realizou-se o método de plaqueamento em superfície o qual consta na adição da amostra diluída em placas contendo PCA e PDA-c, seguido de incubação a $35{ }^{\circ} \mathrm{C} / 48 \mathrm{~h}$ e $25{ }^{\circ} \mathrm{C} / 96 \mathrm{~h}$, respectivamente. Em seguida, foram realizadas as contagens microbianas e os resultados foram expressos em UFC/mL da bebida.

\subsubsection{Análise da água utilizada na planta}

A avaliação microbiológica da água utilizada na planta de processamento seguiu o mesmo procedimento descrito no item 4.2.2. Antes da coleta, a região de saída da água foi higienizada com álcool 70\%, deixando-se escoar a água por um período de 3 minutos, conforme indicado por Silva et al. (2010).

\subsubsection{Análise microbiológica das embalagens}

A análise das garrafas foi feita separada e distintamente das tampas e selos. As garrafas foram divididas em três lotes constando de seis unidades por lote, antes da descontaminação, sendo analisadas a cada duas garrafas. A mesma separação do lote foi realizada após a descontaminação das garrafas.

O procedimento para análise microbiológica das garrafas constou na adição de $50 \mathrm{~mL}$ de solução esterilizada, contendo solução de água peptonada e de tiossulfato de sódio e tenso ativo Tween80, prosseguindo com o fechamento das garrafas e agitação vigorosa e padronizada, como descrito anteriormente no item 4.2.5.

De acordo com a separação dos lotes, as soluções de duas garrafas foram transferidas para um frasco esterilizado para homogeneização; metade da nova solução foi filtrada à vácuo em membrana de celulose com porosidade de $0,45 \mu \mathrm{m}$. 
O mesmo procedimento foi feito para a outra metade da solução. As membranas foram transferidas para placas de petri contendo PCA e PDA-c e incubadas. Os resultados foram expressos em UFC por garrafa.

Em relação às tampas e selos, estes foram separados em 3 (três) lotes contendo 6 tampas em cada lote de amostras antes da esterilização. Após a descontaminação o procedimento foi semelhante ao realizado para as garrafas. Dividiu-se em três lotes constando de seis unidades por lote, porém a contagem microbiana foi feita a cada duas tampas.

A análise das tampas e dos selos de alumínio antes e após esterilização foi realizada por meio do método de esfregaço utilizando o swab, descrito anteriormente.

Após a descontaminação, seguiu-se o procedimento semelhante ao realizado para as garrafas: dividiu-se em três lotes constando de seis tampas por lote, porém a contagem microbiana foi feita a cada duas tampas.

Em todas as amostras analisadas foram feitas a contagem de mesófilos aeróbios em placas com PCA incubadas a $35^{\circ} \mathrm{C} / 48 \mathrm{~h}$ e de bolores e leveduras em placas com PDA-c incubadas a $25^{\circ} \mathrm{C} / 96 \mathrm{~h}$.

\subsubsection{Avaliação microbiológica do produto final}

Três amostras (embalagens) por processamento foram submetidas à contagem de mesófilos totais e bolores e leveduras para avaliação da qualidade microbiológica do produto final.

\subsection{TESTE DE ESTERILIDADE COMERCIAL}

Testes de esterilidade comercial foram realizados para complementar a avaliação microbiológica do produto final.

O teste de esterilidade comercial da bebida acidificada, pasteurizada e acondicionada assepticamente consistiu na incubação do lote recém-processado, a $25 \stackrel{\circ}{ } \mathrm{C}$ por 10 dias, conforme metodologia estabelecida pela American Public Health Association (APHA, 1998) para alimentos ácidos $(\mathrm{pH}<4,6)$ e descrita por Silva et al. (2010). Para tanto, foi retirada uma alíquota de $1 \mathrm{~mL}$ da bebida e transferida 
assepticamente para tubos contendo caldo ácido (CA) e caldo Man, Rogosa e Sharp (MRS) que foram incubados a $30^{\circ} \mathrm{C} / 48 \mathrm{~h}$, e caldo extrato de malte (EM) incubado a $25{ }^{\circ} \mathrm{C} / 96$ h. A ausência de desenvolvimento microbiano nos referidos caldos após a incubação atesta a esterilidade comercial das amostras. Para confirmação de alteração aparente nos caldos foi realizada a caracterização das culturas por meio de plaqueamento em ágar thermoacidurans (TAA), ágar APT e ágar batata dextrose acidificado com cloranfenicol (PDA-c).

\subsubsection{Incubação}

Ao final do processamento, os lotes foram fracionados em três partes, assim estocados: $1 / 3$ a $0{ }^{\circ} \mathrm{C}$ e $1 / 3$ a $25{ }^{\circ} \mathrm{C}$, ambos na ausência de radiação, e 1/3 a temperatura ambiente $\left(19\right.$ a $\left.23^{\circ} \mathrm{C}\right)$.

\subsubsection{Inspeção visual}

Após o período de incubação a $25^{\circ} \mathrm{C}$ e estocagem ambiente durante 10 dias, as amostras foram submetidas a uma inspeção visual para observação de eventuais alterações na embalagem, a considerar: estufamento, falhas na selagem, alterações na aparência, no aroma e no sabor da bebida.

\subsubsection{Determinação de pH}

Nove amostras foram tomadas aleatoriamente, 10 dias após 0 processamento, para leitura do $\mathrm{pH}$, a saber: três estocadas a $25^{\circ} \mathrm{C}$, três estocadas a temperatura ambiente, e as demais a $0{ }^{\circ} \mathrm{C}$ para avaliação comparativa.

\subsection{ANÁLISE SENSORIAL}

\subsubsection{Teste de aceitação do caldo de cana processado}

Conforme Toledo (1974), o sanificante APA, dependendo da concentração da solução utilizada, pode ocasionar odores desagradáveis, resultante de sua 
concentração residual remanescente. Desta forma, foi realizada a análise sensorial para verificar se os provadores identificavam algum sabor ou odor residual no produto processado devido a aplicação do APA como sanificante na linha de processamento e envase, e na descontaminação das embalagens.

Amostras dos três lotes processados foram submetidas ao teste de escala hedônica de sete pontos para avaliar a aceitação do produto, utilizando-se a ficha representada pela Figura 7. O projeto foi submetido ao comitê de ética da FZEA e aprovado conforme descrito no parecer n. 631.732, em 30/04/2014.

Cento e dois provadores com faixa etária entre 17 e 50 anos, consumidores habituais de caldo de cana, avaliaram a aparência, o aroma e o sabor do produto servido a $10^{\circ} \mathrm{C}$, aproximadamente. Testes de intenção de compra complementaram a avaliação sensorial.

Figura 7 - Ficha para avaliação sensorial de caldo cana acidificado e pasteurizado.

FICHA DE AVALIAÇÃO SENSORIAL DE CALDO DE CANA

Nome: Data:

Por favor, avalie a amostra de caldo de cana e indique, utilizando a escala abaixo, o quanto você gostou ou desgostou em relação aos atributos apresentados.

7. gostei muito

6. gostei moderadamente

5. gostei ligeiramente

4. nem gostei/nem desgostei

3. desgostei ligeiramente

2. desgostei moderadamente

1. desgostei muito

AMOSTRA

Aparência

Aroma

sabor

Se encontrasse este produto no mercado:

( ) certamente compraria

( ) provavelmente compraria

( ) talvez compraria/talvez não compraria

( ) provavelmente não compraria

( ) certamente não compraria

Comentários:

Fonte: Própria autoria. 


\subsubsection{Análise de descritores}

Com o intuito de gerar uma terminologia para descrição das características sensoriais do caldo de cana acidificado, aplicou-se um procedimento baseado no Método de Rede (STONE et al., 1974). Assim, desenvolveu-se uma ficha de avaliação das características sensoriais identificadas na bebida (APÊNDICE A).

Uma equipe de 6 (seis) julgadores avaliou a aparência, a textura, o aroma e o sabor. As intensidades dos atributos sensoriais foram avaliadas em escala não estruturada de $9 \mathrm{~cm}$. As amostras foram servidas a temperatura ambiente.

\subsection{ANÁLISE ESTATÍSTICA DOS RESULTADOS}

Os resultados obtidos neste estudo foram tratados estatisticamente pela análise de variância (ANOVA) e teste de Turkey para a comparação de médias entre as amostras ao nível de $5 \%$ de significância e comparados com padrões fixados pela legislação nacional e internacional vigente. Utilizou-se o programa STATISTICA 9 e SAS, versão 9.2 (SAS Institute, Inc., Cary, NC, USA) para o processamento dos dados. 


\section{RESULTADOS E DISCUSSÃO}

\subsection{IDENTIFICAÇÃO DOS PONTOS CRÍTICOS DE CONTROLE (PCC)}

No processamento do caldo de cana foram constatados 3 (três) PCC: as etapas de pasteurização, de envase e de descontaminação das embalagens.

\subsubsection{Tratamento térmico}

A pasteurização visa reduzir ou destruir os micro-organismos patogênicos não esporulados produzindo alimentos mais seguros por meio da aplicação do binômio tempo $\mathrm{x}$ temperatura adequadamente dimensionado. A resistência térmica dos micro-organismos presentes no alimento depende, sobretudo das propriedades intrínsecas do produto, notadamente da atividade de água, do $\mathrm{pH}$ e da composição nutricional. A etapa de pasteurização foi identificada como um PCC, tendo como perigos agentes de natureza biológica, em virtude da inexistência de uma etapa subsequente capaz de eliminar ou reduzir o perigo a níveis seguros. Um provável perigo no caldo de cana é a presença de protozoários e coliformes termotolerantes potencialmente patogênicos.

\subsubsection{Envase}

Outro PCC identificado foi a etapa de envase asséptico para controle da qualidade do ar que precisa ser rigorosamente monitorado. Nesta etapa foram identificados como perigo agentes de natureza biológica, sendo fundamental a manutenção e a troca regular do filtro de ar da câmara de envase. A eficiência do envase também possibilita aumentar a qualidade e o tempo de vida útil do produto.

\subsubsection{Descontaminação das embalagens}

A etapa de descontaminação da embalagem representa um PCC, o qual visa eliminar uma fonte de contaminação potencial, devido ao fato de que o produto após ser acondicionado não passará por nenhuma outra etapa capaz de eliminar tal 
contaminação (JOYCE, 1993; REUTER, 1988).

Os perigos identificados nesta etapa são de natureza biológica, devido a uma eventual presença de contaminantes remanescentes nas embalagens, e de natureza química, considerando um risco potencial oferecido pela eventual presença de resíduos químicos na embalagem.

A identificação de PCCs é uma etapa fundamental para controlar o processamento de alimentos. Para isso, é importante destacar que nem todos os pontos são críticos ou devem ser controlados. O número de PCC deve ser o mínimo possível e, para tanto, a adequada identificação dos perigos e suas medidas de controle devem ser muito elaboradas. Em caso de se identificar grande quantidade de PCC, a tendência é a valorização dos pontos realmente mais relevantes (TONDO; BARTZ, 2011).

Os PCCs podem ser monitorados e registrados para garantir que o processo está sob controle, por isso a importância de identificá-los (TONDO; BARTZ, 2011), como representado na Tabela 3. 
Tabela 3 - Identificação e análise dos pontos críticos de controle (PCC) em uma linha piloto de processamento de caldo de cana acidificado.

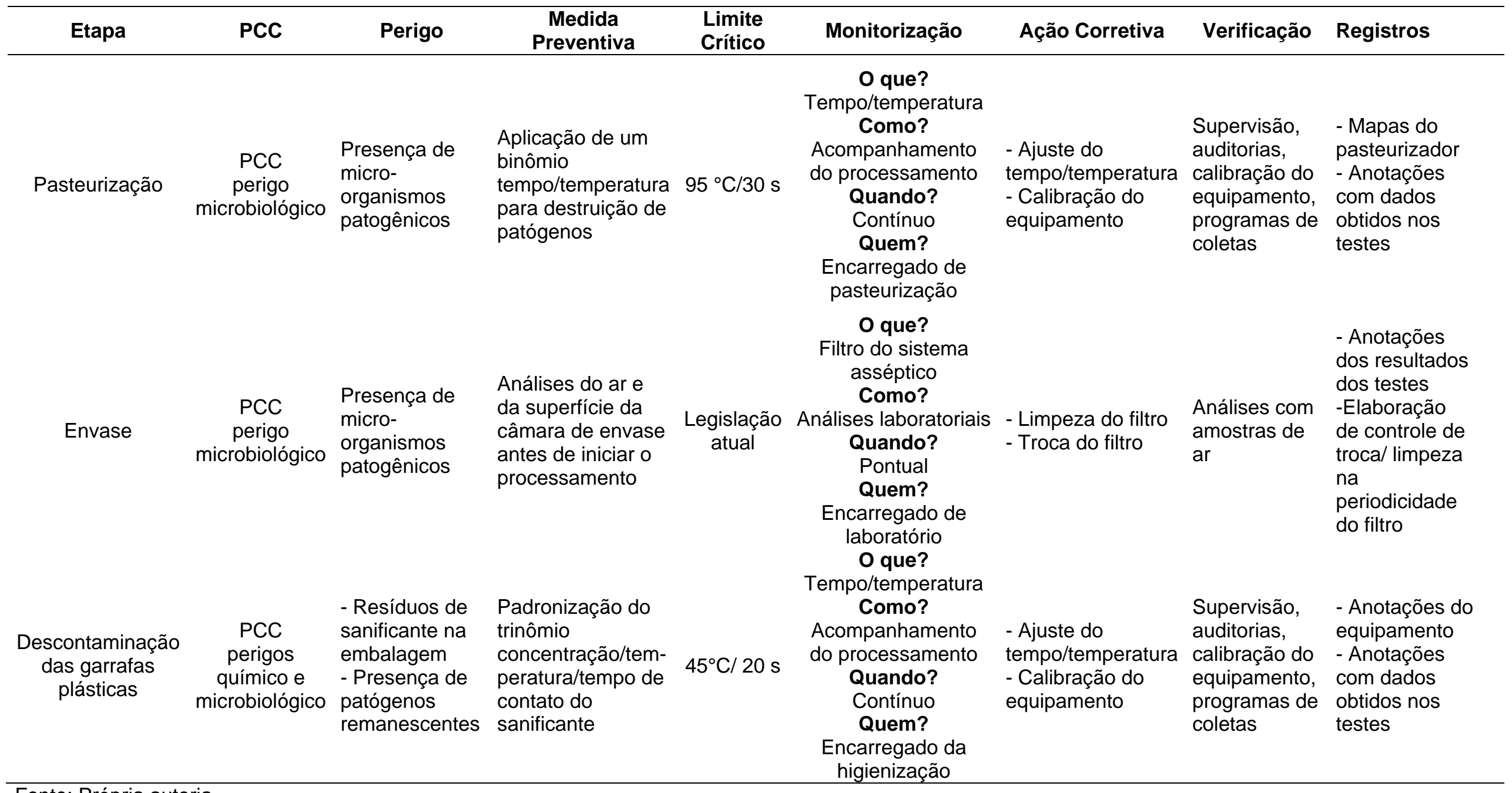




\subsection{ANÁLISE DO CALDO DE CANA IN NATURA}

\subsubsection{Testes físico-químicos}

$\mathrm{Na}$ Tabela 4 constam os valores médios de $\mathrm{pH}$, de sólidos solúveis e de acidez titulável determinados em amostras de caldo de cana recém-extraído nos três processamentos.

Tabela 4 - Valores médios de pH, sólidos solúveis e acidez titulável no caldo de cana recém-extraído.

\begin{tabular}{cccc}
\hline Processamento & $\mathbf{p H}$ & $\begin{array}{c}\text { Sólidos solúveis } \\
\text { ('Brix) }\end{array}$ & $\begin{array}{c}\text { Acidez titulável } \\
\text { (g de ac. cítrico/ } \\
100 \mathrm{~mL} \text { caldo de cana) }\end{array}$ \\
\hline P1 & $5,11 \mathrm{a} \pm 0,01$ & $20,4 \mathrm{c} \pm 0,01$ & $0,050 \mathrm{~b} \pm 0,01$ \\
P2 & $5,07 \mathrm{ab} \pm 0,02$ & $23,7 \mathrm{a} \pm 0,01$ & $0,052 \mathrm{~b} \pm 0,02$ \\
P3 & $5,03 \mathrm{~b} \pm 0,02$ & $22,8 \mathrm{~b} \pm 0,01$ & $0,082 \mathrm{a} \pm 0,03$ \\
\hline
\end{tabular}

Médias seguidas pela mesma letra não diferem entre si $(p>0,05)$, pelo teste de Turkey.

Fonte: Própria autoria.

Resultados semelhantes a este estudo foram obtidos por Gallo e Canhos (1991), com valores de pH entre 5,0 e 5,5 para o caldo de cana in natura. Pode-se observar na Tabela 4 que embora o pH do caldo de cana em P1 e P3 diferiram entre si; contudo, a etapa seguinte de acidificação proporcionou a padronização do produto, destacando a importância desta etapa no processamento.

Com relação ao teor de sólidos solúveis, Oliveira et al. (2007) relataram uma média de 22,7 ${ }^{\circ}$ Brix, valor muito próximo ao encontrado neste trabalho, enquanto que Rezzadori (2010) encontrou um valor inferior, equivalente a 19,35 ${ }^{\circ}$ Brix. Além disso, houve diferença estatística no teor de sólidos solúveis encontrados no caldo de cana extraído. Estas variações podem ser atribuídas a diferentes períodos de maturação da cana-de-açúcar, épocas do ano influenciadas por períodos de estiagem, entre outras.

Para a acidez titulável, Silva e Faria (2006) encontraram 0,056 g de ácido cítrico/ $100 \mathrm{~mL}$ de caldo de cana e Oliveira et al. (2007) indicaram valores de 0,030 a $0,050 \mathrm{~g}$ de ácido cítrico/ $100 \mathrm{~mL}$ de caldo de cana, próximos ao obtido no processamento $\mathrm{P} 1$ e $\mathrm{P} 2$. As amostras dos processamentos $\mathrm{P} 1$ e $\mathrm{P} 2$ não diferiram entre sim ao nível de 5\% de significância. Fato distinto ocorreu em P3 em que foi constatada diferença significativa em relação aos dois processamentos anteriores 
(P1 e P2). Estas variações podem ser atribuídas à colheita tardia da matéria-prima, conforme relatado pelo produtor.

\subsubsection{Testes microbiológicos}

Os resultados apresentados a seguir referem-se às pesquisas de mesófilos aeróbios totais e bolores e leveduras. Contagens de micro-organismos esporulados não foram realizadas porque este grupo não foi alvo das tecnologias de processamento aplicadas neste estudo, uma vez que o caldo de cana foi acidificado ( $\mathrm{pH} 4,3)$, pasteurizado e estocado sob refrigeração. Este fato, contudo, não elimina completamente a possibilidade da incidência de micro-organimos termoacidúricos, a exemplo da espécie bacteriana Alicyclobacillus acidoterrestris, cuja presença tem sido relatada em sucos de fruta de alta acidez.

\subsection{TESTES QUE ANTECEDERAM AOS PROCESSAMENTOS}

Antes da execução dos processamentos de caldo de cana realizaram-se dois testes preliminares com a finalidade de verificar as condições do processo e aprimorar os procedimentos operacionais.

\subsubsection{Análise preliminar da água de enxágue da linha de processamento e envase}

Um esquema ilustrativo da linha de processamento e envase (Figura 8) foi elaborado indicando os pontos em que foram coletadas, em testes preliminares, amostras de água para as análises microbiológicas, incluindo os seguintes pontos: antes do pasteurizador (AP), depois do pasteurizador (DP), depois do tanque (DT) e depois da dosadora (DD). 
Figura 8 - Esquema ilustrativo dos pontos em que foram coletadas amostras de água de enxágue da linha de processamento e envase.

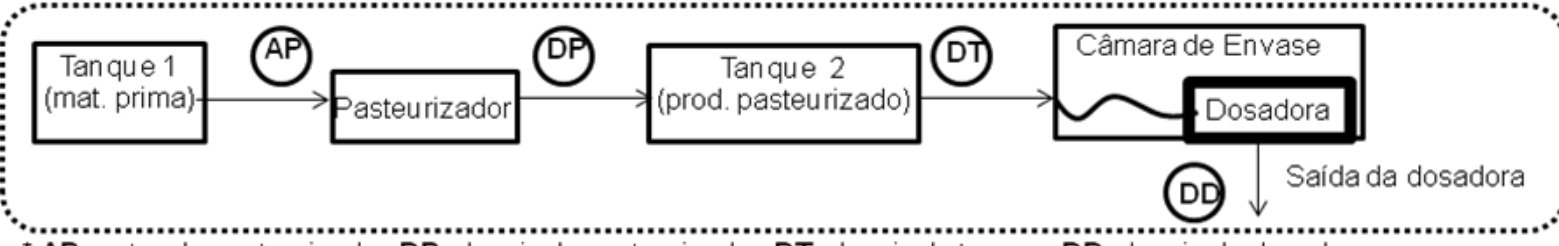

*AP: antes do pasteurizador; DP: depois do pasteurizador; DT: depois do tan que; DD: depois da dosadora.

Fonte: Própria autoria.

Antes da higienização obtiveram-se contagens de mesófilos totais e bolores e leveduras superiores a $6,5 \times 10^{3} \mathrm{UFC} / \mathrm{mL}$. Os resultados após a higienização estão apresentados na Tabela 5. 
Tabela 5 - Valores médios obtidos na contagem microbiana em amostras da água de enxágue da linha de processamento após a higienização.

\begin{tabular}{lcccc}
\hline \multirow{2}{*}{ Pontos de coleta } & \multicolumn{3}{c}{ Depois da higienização (UFC/mL) } \\
\cline { 2 - 5 } & \multicolumn{3}{c}{$\mathrm{T} 1$} & $\mathrm{~T} 2$ \\
\hline & mesófilos totais & bolores e leveduras & mesófilos totais & bolores e leveduras \\
\hline AP & $6,5 \times 10^{-2}$ & $<1,0 \times 10^{-2}$ est. & $<1,0 \times 10^{-2}$ est. & $<1,0 \times 10^{-2}$ est. \\
DP & $<1,0 \times 10^{-2}$ est. & $<1,0 \times 10^{-2}$ est. & $<1,0 \times 10^{-2}$ est. & $<1,0 \times 10^{-2}$ est. \\
DT & $1,6 \times 10^{-1}$ & $<1,0 \times 10^{-2}$ est. & $1,3 \times 10^{-1}$ & $<1,0 \times 10^{-2}$ est. \\
DD & $1,4 \times 10^{-1}$ & $<1,0 \times 10^{-2}$ est. & $2,6 \times 10^{-1}$ & \\
T1: primeiro teste preliminar & & & \\
T2: segundo teste preliminar & & & \\
AP: antes do pasteurizador & & & \\
DP: depois do pasteurizador & & & \\
DT: depois do tanque & & & \\
DD: depois da dosadora & & & \\
est.: valor estimado & & & \\
Fonte: Própria autoria. & & &
\end{tabular}


As médias das contagens em todos os pontos de coleta, anteriores a etapa de higienização, foram superiores a $6,5 \times 10^{3} \mathrm{UFC} / \mathrm{mL}$, indício de contaminação sendo possível aumento da contagem microbiológica no produto final. Devido a estes resultados foram feitas somente as análises das amostras após a higienização.

Conforme a Tabela 5 foi possível verificar que a etapa de higienização proporcionou significativa redução na contagem microbiana em todos os pontos de coleta, de valores superiores a $6,5 \times 10^{3} \mathrm{UFC} / \mathrm{mL}$ para menores que $1,0 \mathrm{UFC} / \mathrm{mL}$.

Por meio da avaliação dos resultados microbiológicos da água de enxágue final nos dois testes preliminares (T1 e T2) e da identificação dos PCC, as análises de água de enxágue durante os três processamentos do caldo foram reduzidas aos pontos depois do pasteurizador (DD) e do envase (DP) após a higienização.

\subsubsection{Análise bacteriológica preliminar da água utilizada na planta de processamento e envase}

A verificação da qualidade microbiológica da água foi feita por meio da enumeração de mesófilos aeróbios totais coletados na saída da torneira e da mangueira, pontos relevantes para recebimento e distribuição da água utilizada na planta. A Tabela 6 apresenta as médias de três repetições obtidas nos dois testes microbiológicos da água feitos antes do processamento do caldo de cana.

Tabela 6 - Valores médios obtidos na contagem de mesófilos aeróbios totais para amostras de água coletadas da torneira e da mangueira utilizadas na planta piloto.

\begin{tabular}{lcc}
\hline TESTES & Mesófilos Aeróbios Totais (UFC/mL) \\
\cline { 2 - 3 } PRELIMINARES & $\begin{array}{c}\text { AMOSTRAS DE ÁGUA } \\
\text { TORNEIRA }\end{array}$ & MANGUEIRA \\
\hline T1 & $<1$ & $>6,5 \times 10^{3}$ est. \\
T2 & $<1$ & $<1_{\text {est }}$ \\
\hline T1: primeiro teste preliminar & & \\
T2: segundo teste preliminar \\
est.: valor estimado - inferior ao limite para contagem em placas. \\
Fonte: Própria autoria.
\end{tabular}

A média obtida no primeiro teste para a mangueira foi elevada, representando uma possível fonte de contaminação. 
Em T2 após os reajustes da linha (substituição da mangueira), verificou-se uma grande redução na contagem das amostras de água coletadas na mangueira > 3,8 reduções decimais.

\subsubsection{Superfície interna da câmara de envase e tanques}

As médias das contagens de micro-organismos obtidas tanto na superfície interna da câmara de envase quanto nos tanques da linha de processamento antes e após a higienização no primeiro e no segundo testes preliminares foram inferiores a 1,0 UFC/ $\mathrm{cm}^{2}$ tanto para mesófilos aeróbios totais quanto para bolores e leveduras. Não foi encontrado na literatura científica consultada dados que correlacionassem a utilização da metodologia utilizada para avaliação de superfície de contato com os micro-organismos analisados neste estudo.

\subsubsection{Ar da planta de processamento e na câmara de envase}

As contagens de mesófilos aeróbios totais e de bolores e leveduras em ambos os testes (T1 e T2) antes e após a higienização foram inferiores a $1 \mathrm{UFC} / \mathrm{cm}^{2}$.min, tanto no ar da planta de processamento quanto no ar da câmara de envase.

A partir destes resultados, notou-se que a análise realizada para contagem de micro-organismos no ar dos referidos locais não demonstrou efeito após o procedimento de higienização. Não foram encontrados na literatura consultada dados relacionados com a técnica de sedimentação aplicada no presente trabalho.

\subsubsection{Embalagens}

Foram realizados dois testes preliminares distintos para as embalagens. No primeiro teste, a contagem de mesófilos aeróbios totais para as garrafas antes da descontaminação foi de 6,6 UFC/garrafa e 3,4 UFC/garrafa para bolores e leveduras. Após a higienização, as contagens de mesófilos e de bolores e leveduras foram equivalentes a 7,3 e 5,1 UFC/garrafa, respectivamente. 
Para as tampas os valores médios encontrados para mesófilos aeróbios, bolores e leveduras antes e após a higienização foram inferiores a 5 UFC/tampa.

Os resultados obtidos antes e após a descontaminação das embalagens foram virtualmente coincidentes, ressaltando-se os baixos de níveis de contaminação inicial das garrafas e das tampas (APÊNDICES B e C).

Assim, foram feitas as alterações necessárias para a realização do segundo teste aumentando o tempo de aspersão do APA de 15 para 20 s, além de melhorar o controle no transporte ao laboratório de microbiologia e durante a análise das embalagens descontaminadas. Para as tampas alterou-se o método aplicado, ou seja, ao invés das tampas serem imersas em solução de APA a 0,05\% por 30 minutos à temperatura ambiente, estas foram esterilizadas em autoclave a $121{ }^{\circ} \mathrm{C}$ por 15 min. Esta mudança foi realizada devido ao acúmulo de solução de APA remanescente nos selos ocasionando problemas na hermeticidade da embalagem.

\subsection{ANÁLISES DE DESEMPENHO DOS PROCESSAMENTOS}

\subsubsection{Avaliação da qualidade microbiológica do caldo de cana in natura}

As médias obtidas nas contagens de mesófilos aeróbios e de bolores e leveduras no caldo de cana recém-extraído foram equivalentes a $1,8 \times 10^{6}$ e $1,6 \times 10^{5}$ UFC/mL, respectivamente.

A Legislação Alimentar Brasileira vigente, por meio da Resolução RDC $n^{\circ} 12$, de 2 de janeiro de 2001 da ANVISA, não estabelece padrões para a contagem total de mesófilos aeróbios e de bolores e leveduras em caldo de cana in natura.

Pesquisas realizadas por Gandra et al.(2007) e Prati (2004) indicaram que contagens de aeróbios mesófilos totais de $10^{6}$ e $10^{7} \mathrm{UFC} / \mathrm{mL}$ podem deflagrar a ocorrência de alterações sensoriais indesejáveis, culminando com a deterioração do produto. Silva et al. (2010) relataram que bolores e leveduras são comumente encontrados em caldo de cana in natura. Oliveira et al. (2007) encontraram contagens equivalentes a $1,4 \times 10^{6} \mathrm{UFC} / \mathrm{mL}$, um ciclo logaritmo superior ao valor médio obtido no presente estudo.

Neste contexto, as médias das contagens obtidas nesta pesquisa indicam a importância da aplicação imediata de tecnologias que inibam ou destruam a 
população contaminante inicial do caldo de cana, visando ao alcance de um tempo de vida útil estendido.

\subsubsection{Análise microbiológica da água de enxágue final da linha de processamento e envase}

A Tabela 7 apresenta os resultados das contagens em amostras da água de enxágue coletadas, após a sanificação da linha com solução de ácido peracético, na saída do pasteurizador e no ponto de envase. Ressalta-se que a água de enxágue foi pasteurizada empregando-se o mesmo binômio $\left(95{ }^{\circ} \mathrm{C} / 30 \mathrm{~s}\right)$ utilizado no tratamento térmico do caldo de cana.

Tabela 7 - Contagens (UFC/100 mL) de mesófilos e bolores e leveduras na água de enxágue final da linha de processamento e no envase.

\begin{tabular}{ccccc}
\hline & \multicolumn{2}{c}{ Linha de processamento $^{1}$} & \multicolumn{2}{c}{ Envase $^{2}$} \\
\cline { 2 - 5 } Processamento & $\begin{array}{c}\text { Mesófilos } \\
\text { totais }\end{array}$ & $\begin{array}{c}\text { Bolores e } \\
\text { leveduras }\end{array}$ & $\begin{array}{c}\text { Mesófilos } \\
\text { totais }\end{array}$ & $\begin{array}{c}\text { Bolores e } \\
\text { leveduras }\end{array}$ \\
\hline P1 & $<1,0$ est & $<1,0$ est. & 5,0 & $<1,0$ est. \\
P2 & 34 & $<1,0$ est. & 35 & 4,7 \\
P3 & 9,3 & 2,0 & 34 & 14 \\
$\begin{array}{l}1-\text { amostragem na saída do pasteurizador. } \\
2-\text { amostragem no ponto de envase. } \\
\text { est.: valor estimado. } \\
\text { Fonte: Própria autoria. }\end{array}$ & & & \\
\end{tabular}

Analisando os dados demonstrados na Tabela 7 pode-se observar que as médias das contagens de mesófilos aeróbios e de bolores e leveduras na água de enxágue foram consideravelmente reduzidas, demonstrando a eficácia dos procedimentos de sanificação implementados.

Salienta-se que nos testes preliminares (T1 e T2) as contagens de mesófilos aeróbios totais e de bolores e leveduras na linha de processamento e envase antes da higienização foram superiores a 6,5 x $10^{3} \mathrm{UFC} / \mathrm{mL}$. 


\subsubsection{Análise da água utilizada na planta}

A técnica de contagem padrão em placas é comumente empregada para indicar, globalmente, as condições higiênicas no processamento de alimentos. Mesmo que os mesófilos quantificados na contagem padrão em placas não sejam de origem fecal a sua presença é indesejada, pois na ocorrência de condições favoráveis à sua multiplicação, estes alteram as características sensoriais do produto diminuindo, como consequência, a vida útil (FRANCO; LANDGRAF, 2003; OLIVEIRA; COSTA; MAIA, 2006; SOUZA; SILVA; SOUSA, 2004).

As médias das contagens de mesófilos aeróbios na água utilizada na planta piloto, nos três processamentos, foram equivalentes a 26; 8,0 e 4,3 UFC/100 mL. Destaca-se a importância do controle microbiológico da água de abastecimento, podendo esta representar uma fonte de contaminação ou recontaminação em uma linha de processamento de alimentos.

De acordo com a Portaria n².914 de 12 de dezembro de 2011 do Ministério da Saúde, os padrões para contagem de bactérias mesófilas aeróbias para água de consumo humano permitem até $5,0 \times 10^{2} \mathrm{UFC} / \mathrm{mL}\left(5,0 \times 10^{4} \mathrm{UFC} / 100 \mathrm{~mL}\right)$. Conforme citado no parágrafo anterior, as contagens de mesófilos aeróbios na água de abastecimento da planta foram inferiores ao referido valor.

\subsubsection{Análise microbiológica das embalagens}

As Tabelas 8 e 9 apresentam os valores médios obtidos nas contagens de micro-organismos presentes nas garrafas, nas tampas e selos antes e após a sua descontaminação. 
Tabela 8 - Contagens microbianas antes e após a descontaminação das garrafas de PET utilizadas no envase de caldo de cana processado.

\begin{tabular}{ccccc}
\hline \multicolumn{4}{c}{ (UFC/garrafa) } \\
\hline \multirow{2}{*}{ Antes } & \multicolumn{2}{c}{ Após } \\
\cline { 2 - 5 } & $\begin{array}{c}\text { Mesófilos } \\
\text { Aeróbios }\end{array}$ & $\begin{array}{c}\text { Bolores e } \\
\text { Leveduras }\end{array}$ & $\begin{array}{c}\text { Mesófilos } \\
\text { Aeróbios }\end{array}$ & $\begin{array}{c}\text { Bolores e } \\
\text { Leveduras }\end{array}$ \\
\hline P1 & $<1$ & $<1$ & $<1$ & $<1$ \\
P2 & $>1,3 \times 10^{2}$ & $<1$ & $<1$ & $<1$ \\
P3 & $<1$ & $<1$ & $<1$ & $<1$ \\
\hline Média de 18 & & & &
\end{tabular}

Média de 18 garrafas.

Fonte: Própria autoria.

Com exceção da média das contagens obtidas nas garrafas utilizadas no processamento 2, antes da descontaminação, os resultados da Tabela 8 mostram que a contaminação inicial das embalagens foi bastante reduzida. Este fato dificultou a avaliação do desempenho da ação do ácido peracético para o fim pretendido, uma vez que as médias das contagens (estimadas) antes e após a descontaminação das embalagens foram inferiores a 1,0 UFC/garrafa (APÊNDICE B). Estes resultados indicam que as embalagens, previamente descontaminadas, não representariam um risco de recontaminação para o caldo de cana acidificado e pasteurizado, estocado sob refrigeração. Não obstante, a etapa de descontaminação das embalagens deve ser monitorada por ser um PCC.

Resultados semelhantes foram encontrados nas tampas e selos esterilizados em autoclave, como mostra a Tabela 9 e APÊNDICE C.

Tabela 9 - Contagens microbianas antes e após a esterilização do conjunto de tampas e selos.

\section{(UFC/ conjunto selo/tampa)}

\begin{tabular}{ccccc}
\hline \multirow{2}{*}{ Processamento } & \multicolumn{2}{c}{ Antes } & \multicolumn{2}{c}{ Após } \\
\cline { 2 - 5 } & $\begin{array}{c}\text { Mesófilos } \\
\text { Aeróbios }\end{array}$ & $\begin{array}{c}\text { Bolores e } \\
\text { Leveduras }\end{array}$ & $\begin{array}{c}\text { Mesófilos } \\
\text { Aeróbios }\end{array}$ & $\begin{array}{c}\text { Bolores e } \\
\text { Leveduras }\end{array}$ \\
\hline P1 & $<1$ & 2,2 & $<1$ & $<1$ \\
P2 & 1,1 & $<1$ & $<1$ & $<1$ \\
P3 & 1,7 & $<1$ & $<1$ & $<1$ \\
\hline
\end{tabular}

Fonte: Própria autoria. 


\subsubsection{Avaliação do produto final}

As médias das contagens de mesófilos aeróbios e de bolores e leveduras na

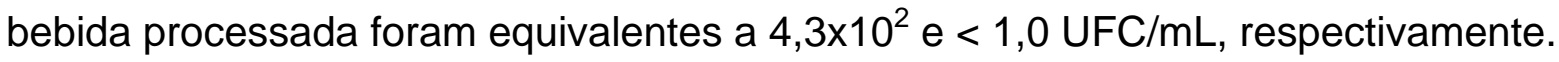

Ao se referir à enumeração de mesófilos aeróbios, Prati, Moretti e Cardello (2005) relataram uma contagem equivalente a $9,0 \times 10^{2} \mathrm{UFC} / \mathrm{mL}$ para caldo de cana acidificado, clarificado, pasteurizado a $75^{\circ} \mathrm{C} / 15 \mathrm{~s}$ e acondicionado em garrafa de PET, valor próximo ao determinado nesta pesquisa.

Em relação a bolores e leveduras, a média das contagens obtida por Prati, Moretti e Cardello (2005) foi de 5,1×10 UFC/mL, a mesma média encontrada por Oliveira et al. (2007), em que foi aplicado ao caldo de cana acidificado um tratamento de $70{ }^{\circ} \mathrm{C} / 25 \mathrm{~min}$, acondicionado em garrafas de polietileno de alta densidade (PEAD).

Nota-se que os trabalhos citados, independentemente do binômio tempo $\mathrm{x}$ temperatura aplicado, apresentaram contagens superiores quando comparados ao presente estudo.

Em contra-partida, Silva e Faria (2006) obtiveram contagens de mesófilos aeróbios totais e bolores e leveduras inferiores a 1,0 UFC/mL em caldo de cana acidificado e processado a $141{ }^{\circ} \mathrm{C} / 10 \mathrm{~s}$, acondicionado a quente e assepticamente em garrafas de vidro.

As Tabelas 10 e 11 comparam as médias das contagens microbianas encontradas no caldo de cana antes e após o seu processamento.

Tabela 10 - Comparação entre as contagens médias de mesófilos aeróbios encontrados no caldo in natura e no caldo acidificado $(p \approx 4,3)$ e pasteurizado.

\begin{tabular}{ccc}
\hline \multirow{2}{*}{ Processamento } & \multicolumn{2}{c}{ Mesófilos aeróbios (LOG UFC/mL) } \\
\cline { 2 - 3 } & Caldo in natura & Produto \\
\hline P1 & $4,3 \mathrm{Ab}$ & $1,6 \mathrm{Ba}$ \\
P2 & $6,3 \mathrm{Aa}$ & $2,9 \mathrm{Ba}$ \\
P3 & $6,5 \mathrm{Aa}$ & $2,6 \mathrm{Ba}$ \\
\hline
\end{tabular}

Médias (três repetições) seguidas pela mesma letra maiúscula (na mesma linha) e pela mesma letra minúscula (na mesma coluna) não diferem entre si $(p>0,05)$.

Fonte: Própria autoria. 
Os dados da Tabela 10 revelaram, para o caldo de cana in natura, que as médias obtidas nas contagens de amostras de P2 e P3 foram dois ciclos logarítmicos superiores à média obtida em P1. Tal fato evidencia a desuniformidade da contaminação microbiana inicial na cana-de-açúcar. Em contraste com o produto processado, não se observou diferença estatística entre as contagens resultantes de amostras dos três processamentos.

Estudos desenvolvidos por Geremias-Andrade (2014), Kunitake (2012) e Suzart (2009) relataram para caldo de cana in natura contagens de microorganismos aeróbios mesófilos de 4,6; 4,8 e 6,8 logUFC/mL, respectivamente. Tais resultados foram similares aos valores encontrados neste estudo.

Outro fato a salientar é que os números de reduções decimais alcançados pelo processamento térmico foram equivalentes a 2,7; 3,4 e 3,9; para P1, P2 e P3, respectivamente. Devido ao ajuste do $\mathrm{pH}$ do caldo de cana in natura e recémextraído a um valor de 4,3 e subsequente tratamento a $95^{\circ} \mathrm{C} / 30 \mathrm{~s}$, esperavam-se números de reduções decimais superiores aos níveis observados.

Porém, segundo Kunitake (2012), os números de reduções decimais alcançados para mesófilos aeróbios em caldo de cana adicionado de polpa de maracujá $(\mathrm{pH} \approx 4)$ e pasteurizado a $95{ }^{\circ} \mathrm{C} / 30$ s foram equivalentes a 2,1, 3,3 e 3,5; valores próximos aos determinados no presente estudo.

Tabela 11 - Comparação entre as contagens médias de bolores e leveduras encontrados no caldo in natura e no caldo acidificado $(p \approx 4,3)$ e pasteurizado.

\begin{tabular}{ccc}
\hline \multirow{2}{*}{ Processamento } & \multicolumn{2}{c}{ Bolores e leveduras (LOG UFC/mL) } \\
\cline { 2 - 3 } P1 & Caldo in natura & Produto \\
\hline P2 & $4,4 \mathrm{a}$ & $<1$ \\
P3 & $4,1 \mathrm{a}$ & $<1$ \\
\end{tabular}

Médias seguidas pela mesma letra não diferem entre si ( $p>0,05)$.

Fonte: Própria autoria.

Em relação a bolores e leveduras, não se observou diferença estatística entre as médias das contagens realizadas em amostras dos três processamentos.

Salienta-se que não foram encontradas colônias de bolores e leveduras nas amostras do produto final, expressando-se desta forma os resultados como valores estimados ( $<1 \mathrm{LogUFC/mL).} \mathrm{Posto} \mathrm{isto,} \mathrm{assumiu-se} \mathrm{que} \mathrm{os} \mathrm{números} \mathrm{de} \mathrm{reduções}$ 
decimais alcançados pelo processamento térmico foram equivalentes a 4,$4 ; 4,1$ e 5,7; para P1, P2 e P3, respectivamente.

Conforme Kunitake (2012), as contagens de bolores e leveduras no caldo de cana in natura variaram de 2,5 a 3,9 logUFC/mL, valores inferiores aos encontrados neste estudo.

Por outro lado, Oliveira et al. (2007) obtiveram contagens de fungos filamentosos e leveduras no caldo de cana adicionado de suco de fruta (limão e abacaxi) de 5 a 6 logUFC/mL. Após o processamento a $70{ }^{\circ} \mathrm{C} / 25$ min observaram-se contagens entre 1 e 2 logUFC/mL.

Finalmente, os resultados das Tabelas 10 e 11 demonstram que as tecnologias de processamento empregadas foram mais efetivas na destruição de bolores e leveduras, comparado à mesófilos aeróbios totais.

\subsection{TESTE DE ESTERILIDADE COMERCIAL}

Com o intuito de aprofundar a investigação acerca da estabilidade microbiológica dos lotes de caldo de cana processados, procedeu-se à realização do teste de esterilidade comercial, cujos resultados estão apresentados a seguir.

\subsubsection{Inspeção visual das amostras}

Após a incubação das amostras a $25^{\circ} \mathrm{C}$ e à temperatura ambiente (entre 19 a $23^{\circ} \mathrm{C}$ ) durante 10 dias, uma equipe de seis pessoas avaliou o produto em busca de alterações aparentes na embalagem, como estufamento, vazamento e colapsagem, e eventual deterioração do aroma, da cor, da aparência e do sabor do produto. Comparado às amostras-controle, estocadas a $0{ }^{\circ} \mathrm{C}$, não foi identificado qualquer indício de deterioração nas dez amostras inspecionadas.

\subsubsection{Determinação do pH}

As médias dos valores de $\mathrm{pH}$ determinados em amostras de cada processamento, após 10 dias de estocagem a 0 , a $25^{\circ} \mathrm{C}$ e à temperatura ambiente, estão apresentadas na Tabela 12. 
Tabela 12 - Valor médio de $\mathrm{pH}$ e desvio-padrão referente ao produto estocado por 10 dias a $0^{\circ} \mathrm{C}$, $25^{\circ} \mathrm{C}$ a temperatura ambiente $\left(\mathrm{T}_{\text {amb. }}\right.$.) nos três processamentos (P1, P2 e P3).

\begin{tabular}{cccc}
\hline \multirow{2}{*}{ Processamento } & \multicolumn{3}{c}{ Temperatura de estocagem } \\
\cline { 2 - 4 } & $\mathbf{0}{ }^{\circ} \mathbf{C}$ & $\mathbf{2 5}^{\circ} \mathbf{C}$ & $\mathbf{T}_{\text {amb. }}$ \\
\hline P1 & $4,38 \mathrm{Ba} \pm 0,01$ & $4,39 \mathrm{Bb} \pm 0,01$ & $4,45 \mathrm{Aa} \pm 0,01$ \\
P2 & $4,37 \mathrm{Ba} \pm 0,01$ & $4,47 \mathrm{Aa} \pm 0,01$ & $4,44 \mathrm{ABa} \pm 0,04$ \\
P3 & $4,33 \mathrm{Bb} \pm 0,01$ & $4,38 \mathrm{Ab} \pm 0,01$ & $4,33 \mathrm{Bb} \pm 0,01$ \\
\hline
\end{tabular}

Médias de três amostras.

Médias seguidas por uma mesma letra minúscula, na mesma coluna (comparação entre processos) e pela mesma letra maiúscula, na mesma linha (comparação entre temperaturas de estocagem) não diferem entre si $(p>0,05)$.

Fonte: Própria autoria.

De acordo com Cerf (1988), o conceito de estabilidade para leite longa vida pressupõe flutuações no $\mathrm{pH}$ do produto inferiores a 0,2. Como não foram localizadas referências na literatura para produtos de alta acidez ( $\mathrm{pH}$ igual ou menor que 4,6) considerou-se a mesma variação de pH como valor de referência para avaliação do caldo de cana acidificado.

Como é possível verificar na Tabela 12 não houve flutuações no $\mathrm{pH}$ da bebida superiores a 0,2 tanto entre os processamentos quanto para as temperaturas de estocagem.

\subsubsection{Testes microbiológicos}

Como não foram identificadas alterações aparentes no produto, procedeu-se à realização de testes microbiológicos para confirmar ou refutar a esterilidade comercial dos lotes. Na condução destes testes identificou-se a presença ou ausência de colônias de micro-organismos nos meios de cultivo. A Figura 9 mostra imagens dos caldos utilizados já adicionados da amostra de caldo de cana. Os meios de cultura para confirmação do crescimento microbiano em placas de petri podem ser observados na Figura 10. 
Figura 9 - Tubos de ensaio com caldo ácido (CA), extrato de malte (EM) e Man, Rogosa e Sharp (MRS) e amostra.

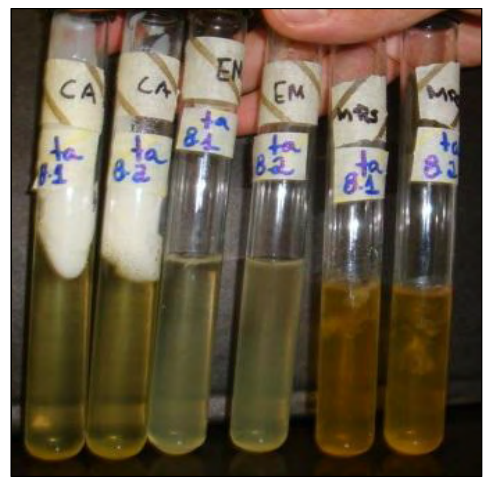

Fonte: Própria autoria.

Figura 10 - Recipientes contendo ágar thermoacidurans (TAA), ágar all purpose tween (APT) e ágar batata dextrose acidificado com cloranfenicol (PDA-C), respectivamente.

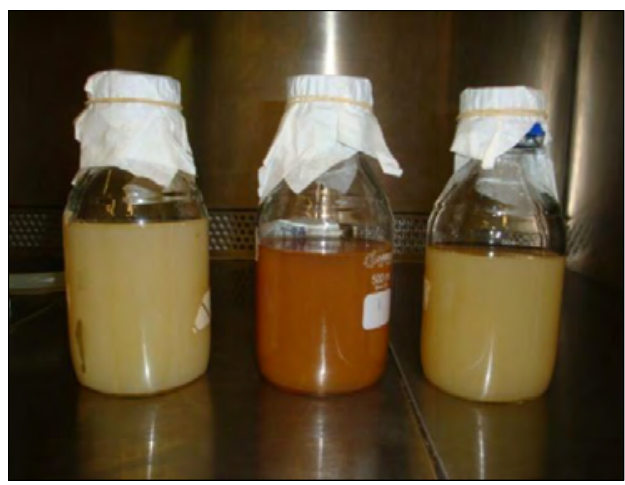

Fonte: Própria autoria.

Tabela 13 - Avaliação das amostras de caldo de cana estocadas a $25^{\circ} \mathrm{C}$ e à temperatura ambiente.

\begin{tabular}{ccccccc}
\hline \multirow{2}{*}{ Processamento } & \multicolumn{3}{c}{$\mathbf{2 5 ^ { \circ } \mathbf { C }}$} & & Tamb. \\
\cline { 2 - 7 } & TAA & PDA-C & APT & TAA & PDA-C & APT \\
\hline P1 & P & A & A & P & A & A \\
P2 & P & A & P & P & A & P \\
P3 & P & A & P & P & A & P \\
\hline
\end{tabular}

A: ausência de desenvolvimento microbiano

P: presença de desenvolvimento microbiano Fonte: Própria autoria.

Pode-se observar na Tabela 13 respostas similares nos três meios (TAA, PDA-c e APT) para as amostras incubadas a $25{ }^{\circ} \mathrm{C}$ e à temperatura ambiente, indicando que o desenvolvimento de microbiano não foi influenciado por oscilações de temperaturas do ambiente ocorridas durante 10 dias de estocagem.

As amostras dos três lotes inoculadas em caldo ácido (CA) produziram gás, e ao realizar a confirmação em placas contendo ágar thermoacidurans (TAA) houve 
desenvolvimento de odor butírico, sugerindo possível presença de bactérias acidúricas mesófias aeróbias e anaeróbias no produto.

Em relação às amostras inoculadas em caldo extrato de malte (EM) não foram identificadas indícios de desenvolvimento microbiano. Desta forma, prosseguiu-se com a inoculação em placas contendo o meio de cultura PDA-c, sendo assim possível constatar ausência de colônias de bolores e leveduras. Ao se referir as amostras inoculadas em caldo MRS e em seguida realizada a inoculação em placas com meio APT, observou-se que somente para as amostras no processamento $\mathrm{P} 1$ não houve desenvolvimento de colônias de bactérias lácticas (Figura 11).

Figura 11 - Resultados do teste de esterilidade comercial em (a) ágar thermoacidurans (TAA) anaerobiose, (b) ágar thermoacidurans (TAA) aerobiose, (c) ágar batata dextrose acidificado com cloranfenicol (PDA-c) e (d) ágar all purpose tween (APT).

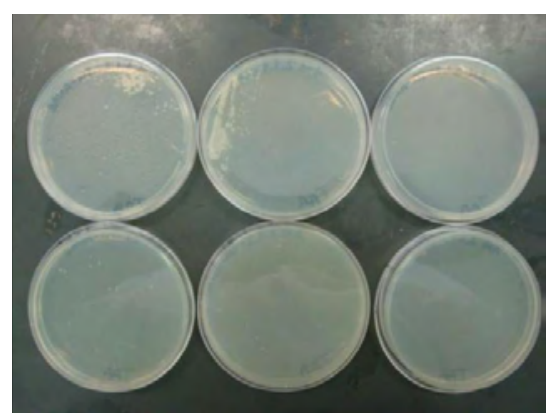

(a)

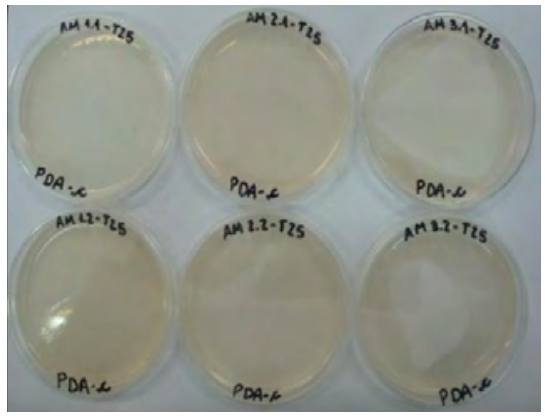

(c)

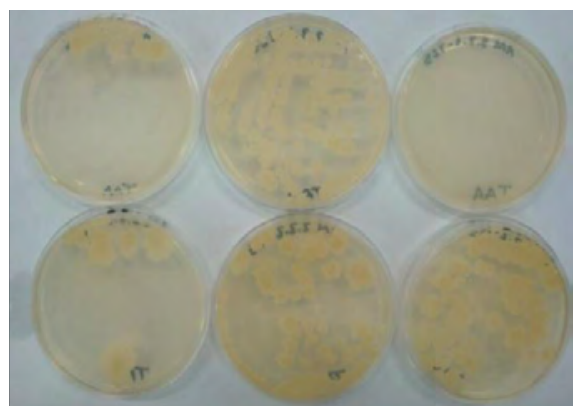

(b)

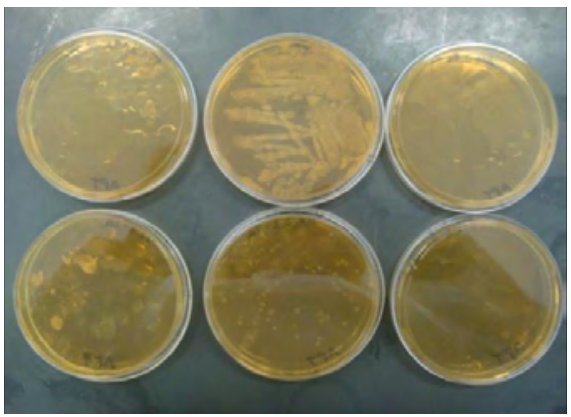

(d)

Fonte: Própria autoria.

De acordo com Silva et al. (2010), o desenvolvimento dos grupos de microorganismos citados podem ser favorecidos por vazamentos na embalagem e/ou subprocessamento, motivos pouco prováveis tendo em vista as condições do processamento e de envase utilizadas nesta pesquisa. 
Segundo Franco e Landgraf (2008), sucos de frutas são susceptíveis ao crescimento de fungos e gêneros de bactérias láticas como Leuconostoc e Lactobacillus tolerantes a açúcares e aos ácidos. No caldo de cana previamente acidificado e pasteurizado não foram identificadas colônias de bolores e leveduras, demonstrando a eficiência das tecnologias de processamento aplicadas no presente estudo.

Apesar da ausência de indícios de deterioração aparente da bebida, constatada na inspeção das amostras dos três lotes de caldo de cana, estes não alcançaram a esterilidade comercial.

\subsection{AVALIAÇÃO SENSORIAL}

A avaliação sensorial dos três lotes processados consistiu na aplicação de testes de escala hedônica, com a finalidade de mensurar o grau de aceitabilidade e a intenção de compra da bebida. Complementarmente, avaliaram-se descritores que poderiam ser atribuídos ao caldo de cana.

\subsubsection{Teste de aceitação}

As médias obtidas nos testes de escala hedônica de sete pontos estão apresentadas na Tabela 14.

Tabela 14 - Médias das notas obtidas nos testes de escala hedônica de sete pontos para os lotes de caldo de cana acidificado ( $\mathrm{pH} \mathrm{4,3)} \mathrm{e} \mathrm{pasteurizado.}$

\begin{tabular}{cccc}
\hline \multirow{2}{*}{ PROCESSAMENTO } & \multicolumn{3}{c}{ (média \pm desvio-padrão / \%aceitação ${ }^{1}$ ) } \\
\cline { 2 - 4 } & Aparência & Aroma & Sabor \\
\hline P1 & $5,84 a \pm 1,24 / 84$ & $5,91 \mathrm{a} \pm 1,20 / 85$ & $6,04 \mathrm{a} \pm 1,24$ / 86 \\
P2 & $6,08 \mathrm{a} \pm 1,11 / 87$ & $6,14 \mathrm{a} \pm 1,00 / 88$ & $5,96 \mathrm{a} \pm 1,21 / 85$ \\
P3 & $5,86 \mathrm{a} \pm 1,27 / 84$ & $6,05 \mathrm{a} \pm 1,02$ / 86 & $5,88 \mathrm{a} \pm 1,32$ / 84 \\
\hline
\end{tabular}

Médias seguidas por uma mesma letra, na mesma coluna, não diferem entre si $(p>0,05)$, em relação à aceitação do produto.

${ }^{1}$ Porcentagem de provadores que atribuiu nota superior a 4 na escala de 7 pontos: (1) desgostei muito, (4) nem gostei/nem desgostei, (7) gostei muito. Número de provadores: 102.

Fonte: Própria autoria.

Os resultados apresentados na Tabela 14 evidenciam a elevada aceitação da bebida, uma vez que as médias de notas para os três atributos avaliados foram 
superiores a 5,8; considerando-se os três processamentos realizados. Analogamente, as porcentagens de aceitação foram muito elevadas, variando entre 84 a $88 \%$. Tais resultados demonstram a elevada qualidade sensorial alcançada pela bebida processada. Outro aspecto importante a mencionar é que as médias não diferiram estatisticamente entre si, sugerindo uma uniformidade da qualidade sensorial do produto.

Conforme Teixeira, Meinert, Barbetta (1987) e Dutcoski (1996), índices acima de $70 \%$ de aprovação revelam uma boa aceitação do produto. Este fato indica que o processamento realizado foi adequado e que os procedimentos de higienização implementados não conferiram aroma e/ou sabor residuais desagradáveis ao caldo de cana.

A Figura 12 apresenta os resultados dos testes de intenção de compra aplicados às amostras de lotes processados.

Figura 12 - Intenção de compra dos lotes de caldo de cana acidificado $(\mathrm{pH} 4,3$ ) e pasteurizado em relação a porcentagem de provadores, nos três processamentos realizados.

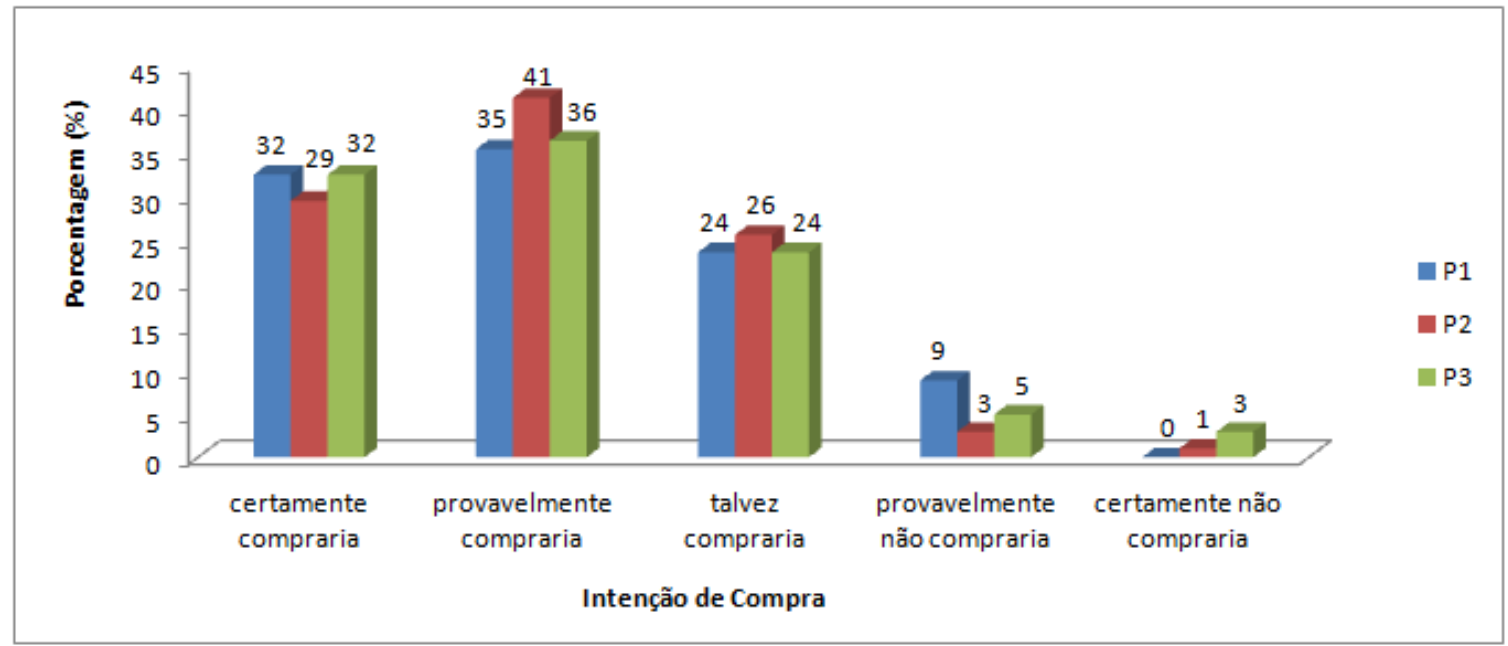

Fonte: Própria autoria.

Conforme representado na Figura 12, 67\%, 70\% e 68\% dos provadores demonstraram atitude favorável a uma eventual compra da bebida resultante dos processamentos $\mathrm{P} 1, \mathrm{P} 2$ e $\mathrm{P} 3$, respectivamente.

Aliado aos dados obtidos nos testes de escala hedônica, tais resultados indicam um bom potencial mercadológico do caldo de cana acidificado e pasteurizado. 


\subsubsection{Análise de descritores}

A Tabela 15 apresenta os resultados da avaliação dos atributos e suas respectivas intensidades, específicos para o caldo de cana em três condições de temperatura de estocagem: $0{ }^{\circ} \mathrm{C}, 25^{\circ} \mathrm{C}$ e temperatura ambiente.

Tabela 15 - Médias das notas atribuídas pelos provadores no julgamento dos descritores estabelecidos para avaliação sensorial de caldo de cana acidificado pasteurizado.

\begin{tabular}{ccccc}
\hline \multirow{2}{*}{ DESCRITOR } & \multicolumn{3}{c}{ Temperatura de Estocagem } \\
\cline { 3 - 5 } Aparência & Cor & $\mathbf{0}{ }^{\mathbf{0}} \mathbf{C}$ & $\mathbf{2 5}{ }^{\circ} \mathbf{C}$ & ambiente \\
\hline \multirow{2}{*}{ Textura } & Turvação & 0,7 & 0,8 & 1,5 \\
& Viscosidade & 0,7 & 1,8 & 0,5 \\
\hline \multirow{4}{*}{ Odor/Aroma } & Ácido & 0,4 & 1,7 & 1,2 \\
& Doce & 4,4 & 0,8 & 1,4 \\
& Caramelo & 1,0 & 0,4 & 0,7 \\
& Fermentado & 0,2 & 4,1 & 3,1 \\
& Alcóolico & 0,0 & 3,5 & 2,5 \\
\hline \multirow{3}{*}{ Gosto } & Doce & 5,1 & 2,1 & 3,2 \\
& Ácido & 0,4 & 1,8 & 2,5 \\
& Amargo & 0,6 & 2,6 & 2,3 \\
\hline \multirow{2}{*}{ Sabor } & Adstringência & 0,3 & 2,6 & 2,6 \\
& Caramelo & 0,9 & 0,6 & 0,9 \\
& Equilíbrio & 4,5 & 0,8 & 1,3 \\
& Sabor Residual & 1,5 & 3,0 & 3,8 \\
& Alcóolico & 0,2 & 6,8 & 7,0 \\
\hline
\end{tabular}

Escala não estruturada de $9 \mathrm{~cm}$.

Fonte: Própria autoria.

Os resultados apresentados na Tabela 15 mostram que os valores médios atribuídos às amostras estocadas durante 10 dias a $0{ }^{\circ} \mathrm{C}$ para odor/aroma e gosto doce foram 4,4 e 5,1, respectivamente. Valores inferiores foram obtidos para os mesmos atributos a $25{ }^{\circ} \mathrm{C}$ e a temperatura ambiente. Por outro lado, ao comparar as médias atribuídas a $0{ }^{\circ} \mathrm{C}$ para odor/aroma e sabor alcoólico, em sequência, de 0 e 0,2 com os referidos atributos a $25^{\circ} \mathrm{C}$ e a temperatura ambiente, os valores foram menores. Desta forma, o caldo de cana quando estocado a $0{ }^{\circ} \mathrm{C}$ manteve suas características sensoriais agradáveis durante 10 dias. Porém, quando estocado a 
$25{ }^{\circ} \mathrm{C}$ ou a temperatura ambiente no mesmo período a bebida sofreu início no processo fermentativo, sendo menos perceptível o odor/aroma e o gosto doce, sobressaindo o alcoólico.

Estes resultados indicam que a combinação de acidificação, do tratamento térmico e do envase asséptico aplicados no presente estudo foram insuficientes para se alcançar a esterilidade comercial do produto. Diante destes resultados, a refrigeração insere-se com um obstáculo complementar necessário para preservar a qualidade do caldo de cana. 


\section{CONCLUSÕES}

A identificação e a análise dos pontos críticos de controle da linha de processamento e envase de caldo de cana em escala piloto favoreceu a monitoração daqueles durante o processamento.

Os valores de $\mathrm{pH}$, do teor de sólidos solúveis e de acidez titulável determinados para o caldo de cana recém-extraído estavam de acordo com a literatura, fortalecendo a caracterização da bebida in natura.

Os resultados das análises microbiológicas foram satisfatórios, fato evidenciado pela significativa redução da população de micro-organismos mesófilos aeróbios totais e pela ausência de colônias de bolores e leveduras no produto final.

Embora a esterilidade comercial não tenha sido alcançada, o caldo de cana acidificado pasteurizado atingiu elevado nível de aceitação sensorial, revelando-se a refrigeração um obstáculo complementar, essencial para a conservação do produto.

Finalmente, os resultados obtidos a partir da avaliação microbiológica da matéria-prima, das embalagens, do produto final e da linha de processamento e envase indicam que esta encontra-se apta à uma eventual micro-escala de produção de caldo de cana acidificado pasteurizado e estocado sob refrigeração. 


\section{SUGESTÕES PARA PESQUISAS FUTURAS}

- Desenvolvimento de uma Análise Descritiva Quantitativa (ADQ) para o caldo de cana integral e acidificado.

- Elaboração de um plano detalhado de Análise de Perigos e Pontos Críticos de Controle (APPCC) para o processamento de caldo de cana, integral e acidificado.

- Estudo da vida útil do produto acondicionado em diferentes sistemas de embalagem.

- Investigação da adição de conservadores químicos ao caldo de cana como eventuais sucedâneos da refrigeração, visando à economia de energia consumida na cadeia do frio.

- Estudo da aplicação de novas tecnologias de processamento ou combinação destas para o caldo de cana.

- Análise do efeito da radiação em diferentes embalagens para o caldo de cana.

- Estudo da adição de novos sabores ao caldo de cana, por exemplo, hortelã, gengibre, outros. 


\section{REFERÊNCIAS BIBLIOGRÁFICAS}

ALVES, R. M. V.; GARCIA, E. E. C. Embalagem para sucos de frutas. Coletânea do Instituto de Tecnologia de Alimentos, v. 23, n. 2, p.105-122, jul./dez. 1993.

ANDRADE, N. J. Higienização na indústria de alimentos: avaliação e controle da adesão e formação de biofilmes bacterianos. São Paulo: Varela, 2008. 412p.

ANDRADE, N. J.; MACEDO, J. A. B. Higienização na indústria de alimentos. São Paulo: Varela, 1996.182p.

ANSARI, M. D. I. A.; DATTA, A. K. An overview of sterilization methods for packaging materials used in aseptic packaging systems. Food and Bioproducts Processing, v. 81 , n. 1 , p. $57-65,2003$.

ATHAYDE, A. Higienização na indústria de laticínios colabora no controle total da qualidade. Engenharia de Alimentos, São Paulo, n. 18, p. 24-29, 1998.

BRASIL. Ministério da Saúde. Agência Nacional de Vigilância Sanitária (Org.). Resolução - RDC n.o 12, de 2 de janeiro de 2001: Regulamento técnico sobre padrões microbiológicos para alimentos. Disponível em:

<http://portal.anvisa.gov.br/wps/wcm/connect/a47bab8047458b909541d53fbc4c6735 /RDC_12_2001.pdf?MOD=AJPERES>. Acesso em: 15 out. 2015.

BRASIL. Ministério da Saúde. Portaria n. ${ }^{\circ}$ 2.914, de 12 de dezembro de 2011: Dispõe sobre os procedimentos de controle e de vigilância da qualidade da água para consumo humano e seu padrão de potabilidade. Disponível em:

<http://bvsms.saude.gov.br/bvs/saudelegis/gm/2011/prt2914_12_12_2011.html> Acesso em 17 jan. 2015.

BUCHELI, C. S.; ROBINSON, S. P. Contribution of enzymic browning to color in sugarcane juice. Journal of Agricultural and Food Chemistry, Washington, v. 42, p. 257-261, 1994.

CARVALHO, L. R., MAGALHÃES, J. T. Avaliação da qualidade microbiológica dos caldos de cana comercializados no centro de Itabuna - BA e práticas de produção e higiene de seus manipuladores. Revista Baiana de Saúde Pública, llhéus, v. 31, n. 2, p. 238-245, 2007.

CASTRO, P. S.; COBUCCI, R. M. A.; GALERA, J. S. Determinação de vida útil de alimentos. In: Semana de Engenharia de Alimentos da Universidade Católica de Goiás, 11. Goiânia, 2008.

CERF, O. Aseptic processing in the food industry - statistical control of uht milk. In: REUTER, H. Aseptic Packaging of Food. Hamburg: Technomic, 1988. cap.6.2, p. 244-257.

CÉSAR, M. A. A. et al. Capacidade de fosfatos naturais e artificiais em elevar o teor de fósforo no caldo de cana-de-açúcar (cana-planta), visando o processo industrial. 
STAB, v. 6, p. 32-38, 1987.

CHIRIFE, J.; FAVETTO, G. J. Some physico-chemical basis of food preservation by combined methods. Food Research International, v. 25, p. 386-96, 1992.

CNC/CNI/SEBRAE/ANVISA. Elementos de apoio: boas práticas e sistema APPCC. Rio de Janeiro: SENAC/DN. 2001. 303p.

CRAMER, M. M. Food plant sanitation: design, maintenance and good manufacturing practices. NW: CRC Press. 2006.

DUTCOSKI, S. D. Análise sensorial de alimentos. Curitiba: Editora Universitária, Champagnat, $1996.123 \mathrm{p}$.

FARIA, M. S. L. Avaliação dos conceitos e procedimentos de limpeza e desinfecção em estabelecimentos alimentares. 2010. 96f. Dissertação (Mestrado) - Faculdade de Medicina Veterinária, Universidade Técnica de Lisboa, Lisboa, 2010.

FELLOWS, P. J. Tecnologia de processamento de alimentos: princípios e prática. Porto Alegre: Artmed, 2. ed., 2006. 602p.

FIGUEIREDO, R. M. SSOP: Padrões e procedimentos operacionais de sanitização; PRP: Programa de redução de patógenos; manual de procedimentos e desenvolvimento. São Paulo: R.M. Figueiredo, 1999. 164p.

FRANCO, B. D. G. M; LANDGRAF, M. Microbiologia de Alimentos. 1. ed., São Paulo: Atheneu. 2008. 182p.

GALLO, C. R.; CANHOS, V. P. Contaminantes bacterianos na fermentação alcoólica - Revisão STAB. Açúcar, Álcool e Subprodutos, v. 9, p. 35-40, 1991.

GANDRA, E. A. et al. Condições microbiológicas de caldos de cana comercializados em Umuarama (PR). Revista Brasileira de Tecnologia Agroindustrial, Ponta Grossa, v. 1, n. 2, p. 61-69, 2007.

GAVA, A. J. Princípios de tecnologia de alimentos. São Paulo: Nobel, 1978.

GEREMIAS-ANDRADE, I. M. Estimativa da vida de prateleira de caldo de cana padronizado estocado sob refrigeração. 2014. $162 \mathrm{f}$. Dissertação (Mestrado) Faculdade de Zootecnia e Engenharia de Alimentos, Universidade de São Paulo, Pirassununga, 2014.

GIBSON, H. et al. Effectiveness of cleaning techniques used in the food industry in terms of the removal of bacterial biofilms. Journal of Applied Microbiology, Oxford, v. 87, p. 41-48, 1999.

GIORDANO, J. C.; GALHARDI, M. G. Análise de perigos e pontos críticos de controle-APPCC. Campinas: SBCTA, 2004. 92p.

GRAUMLICH, T. R.; MARCY, J. E.; ADAMS, J. P. Asseptically packaged orange juice 
and concentrate: a review of the influence of processing and packaging conditions on quality. Journal of Agricultural and Food Chemistry, v. 34, n. 3, p. 402-405, 1986.

JAY, J. M. Microbiologia de alimentos. 6. ed. Porto Alegre: Artmed, 2005. 711p.

JOYCE, D.A. Microbiological aspects of aseptic processing and packaging. In: WILLHOFT, E. M. Aseptic processing and packaging of particulates foods. Glasgow: Blackie Academic \& Professional, 1993. cap. 8, p.155-180.

KATHARIOU, S. Listeria monocytigenes virulence and pathogenicity, a food safety perspective. Journal of Food Protection, Ames, v. 65, n. 11, p. 1811-1829, 2002.

KITOKO, P. M.; OLIVEIRA, A. C.; SILVA, M. L. Avaliação microbiológica do caldo de cana comercializado em Vitória, Espírito Santo, Brasil. Higiene Alimentar, n. 119, v. 18, p. 73-76, 2004.

KUNITAKE, M. T. Processamento e estabilidade de caldo de cana acidificado. 2012. 129f. Dissertação (Mestrado) - Faculdade de Zootecnia e Engenharia de Alimentos, Universidade de São Paulo, Pirassununga, 2012.

LANGSRUD, S. et al. Bacterial disinfectant resistence a challenge for the food industry. International Biodeterioration e Biodegradation, Oxford, v. 51, n. 4, p. 283-290, 2003.

LEISTNER, L.; GORRIS, L. G. M. Food preservation by hurdle technology. Trends in Food Science Technology, v. 6, p. 41-6, 1995.

LEISTNER, L. Shelf stable products and intermediate moisture foods based on meats. In: ROCKLAND, L.B., BEUCHAT, L.R. Water activity: theory and application to foods. New York: Marcel Dekker, p. 295-327, 1987.

LELIEVELD, H.; MOSTERT, M.; HOLAH, J. Handbook of hygiene control in the food industry. USA: Woodhead Publishing Limited. 2005.

LEVI, A.; GAGEL, S.; JUVEN, B. J. Intermediate-moisture tropical fruit products for developing countries. II. Quality characteristics of papaya. Journal of Food Technology, v. 20, p. 163,1985.

LOPES, G.; CRESTO, R.; CARRARO, C. N. M. Análise microbiológica de caldos de cana comercializados nas ruas de Curitiba, PR. Higiene Alimentar, v. 20, n. 147, p. 40-44, 2007.

MACEDO, J. A. B. Águas e águas. Belo Horizonte: Ortfofarma, 2000. 505p.

MCLELLAN, M. R.; PADILLA-ZAKOUR, O. I. Juice processing. In: BARRETT, D.; SOMOGYI, L.; RAMASWAMY, H. Processing fruits: science and technology. 2. ed. Boca Raton: CRC Press, 2005.

MOSSEL, D. A. A.; GARCÍA, B. M.; STRUIJK, C. B. Microbiología de los alimentos. 2 ed. Zaragoza: Editorial Acribia, S. A., 2003. p 89-98. 
OLIVEIRA, A. C. G. et al. Análise das condições do comércio de caldo de cana em vias públicas de municípios paulistas. Segurança Alimentar e Nutricional, Campinas, v. 13, n. 2, p. 6-18, 2006.

OLIVEIRA, A. C. G. et al. Efeitos do processamento térmico e da radiação gama na conservação de caldo de cana puro e adicionado de suco de frutas. Ciência e Tecnologia de Alimentos, Campinas, v. 27, n. 4, p. 863-873, 2007.

OLIVEIRA, A. M. C.; COSTA, J. M. C.; MAIA, G. A. Qualidade higiênico-sanitária de abacaxi-"pérola" minimamente processado. RBPS, v. 19, n. 1, p. 19-24, 2006.

ONTARIO MINISTRY OF AGRICULTURE, FOOD AND RURAL AFFAIRS (OMAFRA). Foods of plant origin cleaning and sanitation guidebook. Disponível em:

$<$ http://www.omafra.gov.on.ca/english/food/inspection/fruitveg/sanitation_guide/csguidebook.htm\#biofilm>. Acesso em: 25 fev. 2015.

PARKAR, S. G.; FLINT, S. H.; BROOKS, J. D. Physiology of biofilms of thermophilic bacilli: potential consequences for cleaning. Journal of Industrial Microbiology and Biotechnology, Hampshire, v. 30, n. 9, p. 553-560, 2003.

PASTER, T. The HACCP food safety training manual. New Jersey: John Wiley \& Sons, 2006. 352p.

PRATI, P. Desenvolvimento de processo de estabilização de caldo de cana adicionado de sucos de frutas ácidas. 2004. Tese (Doutorado) - Faculdade de Engenharia de Alimentos, Universidade Estadual de Campinas, Campinas, 2004.

PRATI, P.; MORETTI, R. H.; CARDELLO, H. M. A. B. Elaboração de bebida composta por mistura de garapa parcialmente clarificada-estabilizada e sucos de frutas ácidas. Ciência e Tecnologia de Alimentos, Campinas, v. 25, n. 1, p. 147152, jan./mar. 2005.

REUTER, $H$. Evaluation criteria for aseptic filling and packaging systems. In: REUTER, H. Aseptic packaging of food. Pennsylvania: Technomic. 1988. cap. 4, p. 95-108.

REZZADORI, K. Pasteurização térmica e com membranas de caldo de cana adicionado de suco de maracujá. 2010. 161f. Dissertação (Mestrado) Universidade Federal de Santa Catarina, Florianópolis, 2010.

SANDEEP, K. P.; SIMUNOVIC, J.; SWARTZEL, K. R. Developments in aseptic processing. In: RICHARDSON, p. (Ed.). Improving the thermal processing of foods. Cambridge: Woodhead, 2004. chap. 9, p. 177-188.

SARANTÓPOULOS, C. I. G. L.; JESUS JUNIOR, I. A. Embalagens plásticas esterilizáveis - reinvenção e tendências. Informativo do Centro de Tecnologia em Embalagens - CETEA. 2007.

SERVIÇO NACIONAL DE APRENDIZAGEM INDUSTRIAL (SENAI). Guia para 
elaboração do Plano APPCC. Série Qualidade e Segurança Alimentar. Projeto APPCC. 2. ed. Convênio CNI/Senai/Sebrae, Brasília, 2000.

SILVA, F. C.; CESAR, M. A. A.; SILVA, C. A. B. Pequenas indústrias rurais de cana-de-açúcar: melado, rapadura e açúcar mascavo. Brasília: Embrapa, 2003. $155 p$.

SILVA, J. A. Tópicos da tecnologia de alimentos. São Paulo: Varela, 2000.

SILVA, K. S.; FARIA, J. A. F. Avaliação da qualidade de caldo de cana envasado a quente e por sistema asséptico. Ciência e Tecnologia de Alimentos, Campinas, v. 26, n. 4, p. 754-758, out./dez. 2006.

SILVA, N. et al. Manual de métodos de análise microbiológica de alimentos e água. 4. ed. São Paulo: Varela, 2010. 624p.

SOLOMONS, T. W. G.; FRYHLE, C. B. Química orgânica. Rio de Janeiro: LTC, 2006. 542p.

SOUZA, E. L.; SILVA, C. A.; SOUSA, C. P. Qualidade sanitária de equipamentos, superfícies, água e mãos de manipuladores de alguns estabelecimentos que comercializam alimentos na cidade de João Pessoas, PB. Revista Higiene Alimentar, v. 18, n. 116-117, p. 98-102, 2004.

SPEERS, J. G. S.; GILMOUR, A. The influence of milk and milk components on the attachment of bacteria to farm dairy equipment surfaces. Journal of Applied Bacteriology, Oxford, v. 59, n. 4, p. 325-332, 1985.

SPRENGER, R. A. Hygiene for management: focus on food safety. 12. ed. Reino Unido: Highfield Publications. 2005.

STONE, $\mathrm{H}$. et al. Sensory evaluation by quantitative descriptive analysis. Food Technology, v. 28, n. 11, p. 24-34,1974.

STUPIELLO, J. P. A cana-de-açúcar como matéria-prima. In: PARANHOS, S. B.

Cana-de-açúcar: cultivo e utilização. Campinas: Fundação Cargill, p. 30-51, 1987.

SUZART, C. A. G. Desenvolvimento de tecnologia para estabilização física, sensorial e microbiológica de caldo de cana. 2009. Dissertação (Mestrado em Tecnologia de Alimentos), Faculdade de Engenharia de Alimentos, Universidade Estadual de Campinas. (UNICAMP), Campinas, 2009.

TEIXEIRA, E.; MEINERT, E. M.; BARBETTA, P. A. Análise sensorial de alimentos. Florianópolis: UFSC, 1987.

TOLEDO, R. T. Trends in Packaging. Proceedings of Ninth Annual Symposium, New York State Agriculture Experiment Station. p. 6, 1974.

TONDO, E. C.; BARTZ, S. Microbiologia e sistemas de gestão da segurança de alimentos. 1. ed., Porto Alegre: Sulina, 2011. 263p. 
VEISSEYRE, R. Lactologia técnica: composición, recogida, tratamiento y transformación de la leche. 2. ed. Zaragoza: Acribia, 1988. 629p.

YUSOF, S.; SHIAN, L. S.; OSMAN, A. Changes in quality of sugar-cane juice upon delayed extraction and storage. Food Chemistry, v. 68, n. 4, p. 395-401, 2000.

WALTON, J.T. et al. Investigation into the effect of detergents on disinfectant susceptibility of attached Escherichia coli and Listeria monocytogenes. Journal of Applied Microbiology, Oxford, v. 105, p. 309-315, 2008.

WELTI-CHANES, J.; VERGARA-BALDERAS, F.; LOPEZ-MALO, A. Minimally processed foods. State of the art and future. In: FITO, P.; ORTEGA-RODRIGUEZ, E.; BARBOSA-CANOVAS, G.V. Food Engineering. New York: Chapman and Hall. 2000. cap. 11 , p. $181-212$

WILDBRETT, G. Limpieza y desinfección en la industria alimentaria. Espanha: Editorial Acribia, S.A. 2006. 
APÊNDICE 


\section{APÊNDICE A - FICHA PARA INSPEÇÃO DAS AMOSTRAS E ANÁLISE DE DESCRITORES}

FICHA PARA ANÁLISE SENSORIAL DE CALDO DE CANA

FICHA №

REPETIÇÃO

NOME:

DATA:

Você recebeu uma amostra de caldo de cana. Por favor, prove a amostra e marque na escala não estrutura a intensidade percebida de cada atributo.

\section{EMBALAGEM}

Estufamento

( ) sim ( ) não comentários:

Selagem adequada

( ) sim ( ) não comentários:

Amassamento

( ) sim ( ) não comentários:

Alteração aparente

( ) sim ( ) não comentários:

\section{APARÊNCIA}

Cor

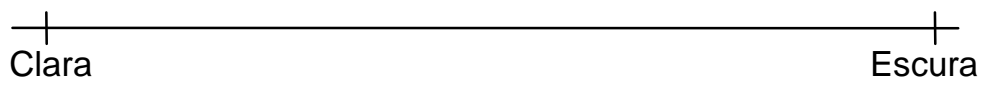

Turvação

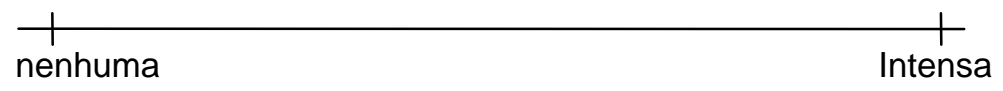

TEXTURA

Viscosidade

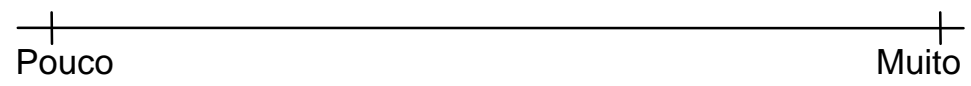

ODOR/AROMA

Ácido

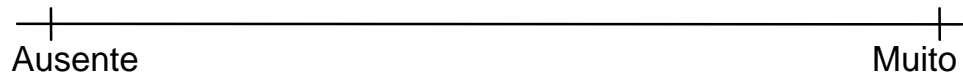

Doce

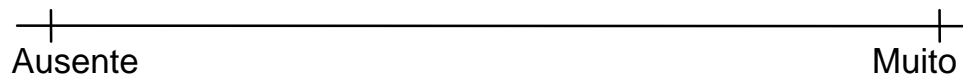

Caramelo

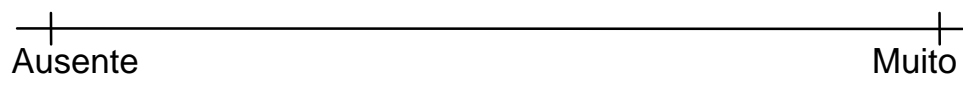

Fermentado

Ausente Muito

Alcoólico 
GOSTO/SABOR

Doce

$\underset{\text { Fraco }}{+1}$

Ácido

Fraco $\quad$ Forte

Amargo

$\underset{\text { Fraco }}{+}$

Adstringência

Ausente Forte

Caramelo

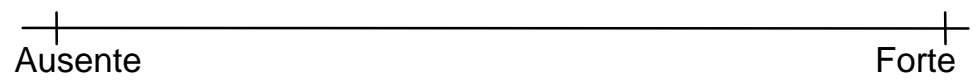

Equilíbrio

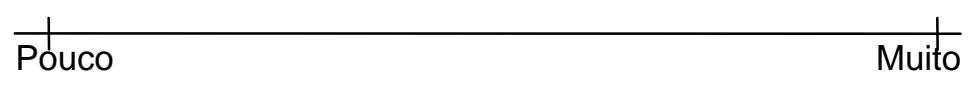

Sabor residual $\frac{1}{\text { Pouco }}+\frac{1}{\text { Muito }}$

Alcoólico

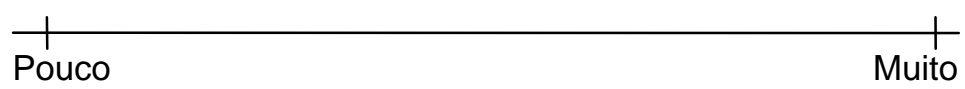

COMENTÁRIOS 
APÊNDICE B - RESULTADOS DOS TESTES PRELIMINARES PARA ANÁLISES MICROBIOLÓGICAS DAS EMBALAGENS
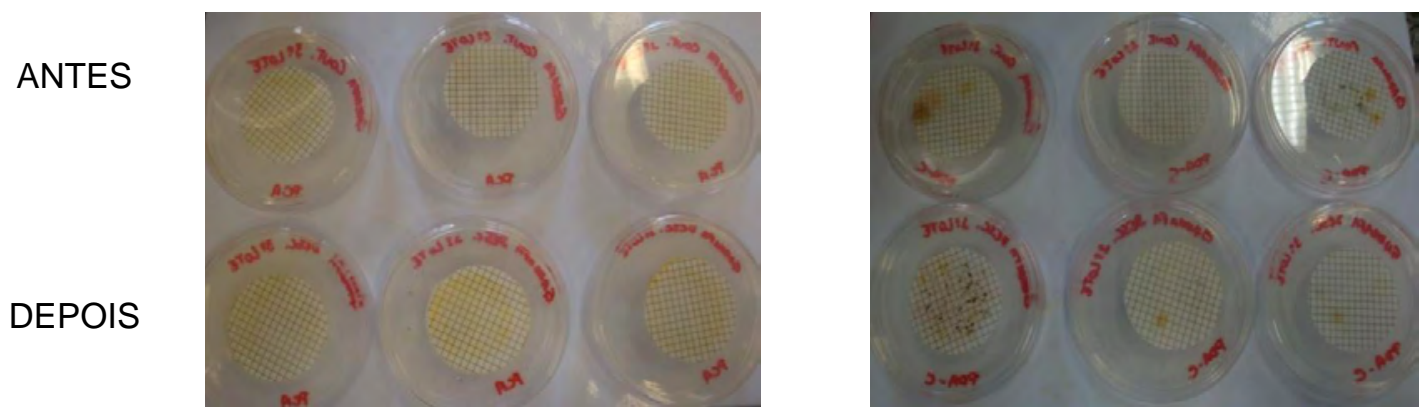

Resultados da análise microbiológica das garrafas de PET antes e após descontaminação. Placas com PCA (esquerda) e com PDA-c (direita).

ANTES
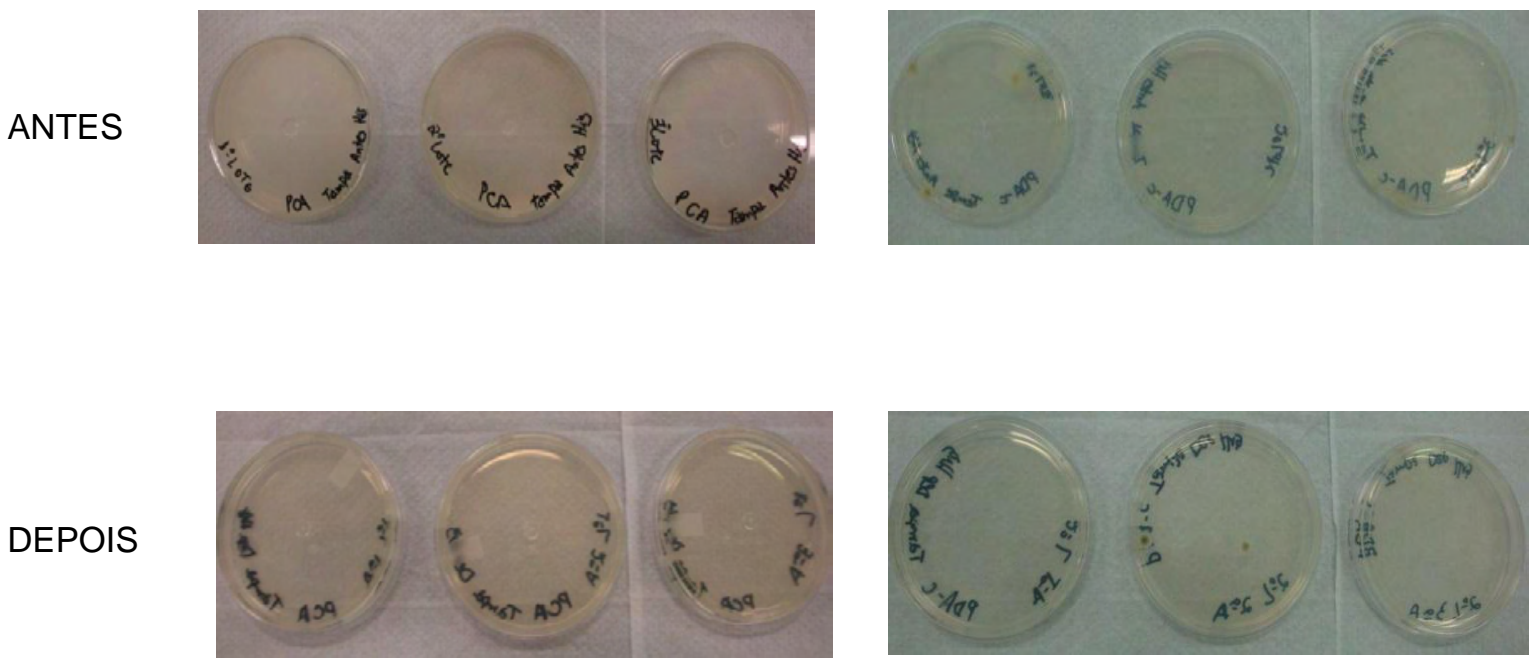

Resultados da análise microbiológica das tampas antes e após a descontaminação. Placas com PCA (esquerda) e com PDA-c (direita). 


\section{APÊNDICE C - RESULTADOS DOS PROCESSAMENTOS REALIZADOS PARA ANÁLISES MICROBIOLÓGICAS DAS EMBALAGENS}
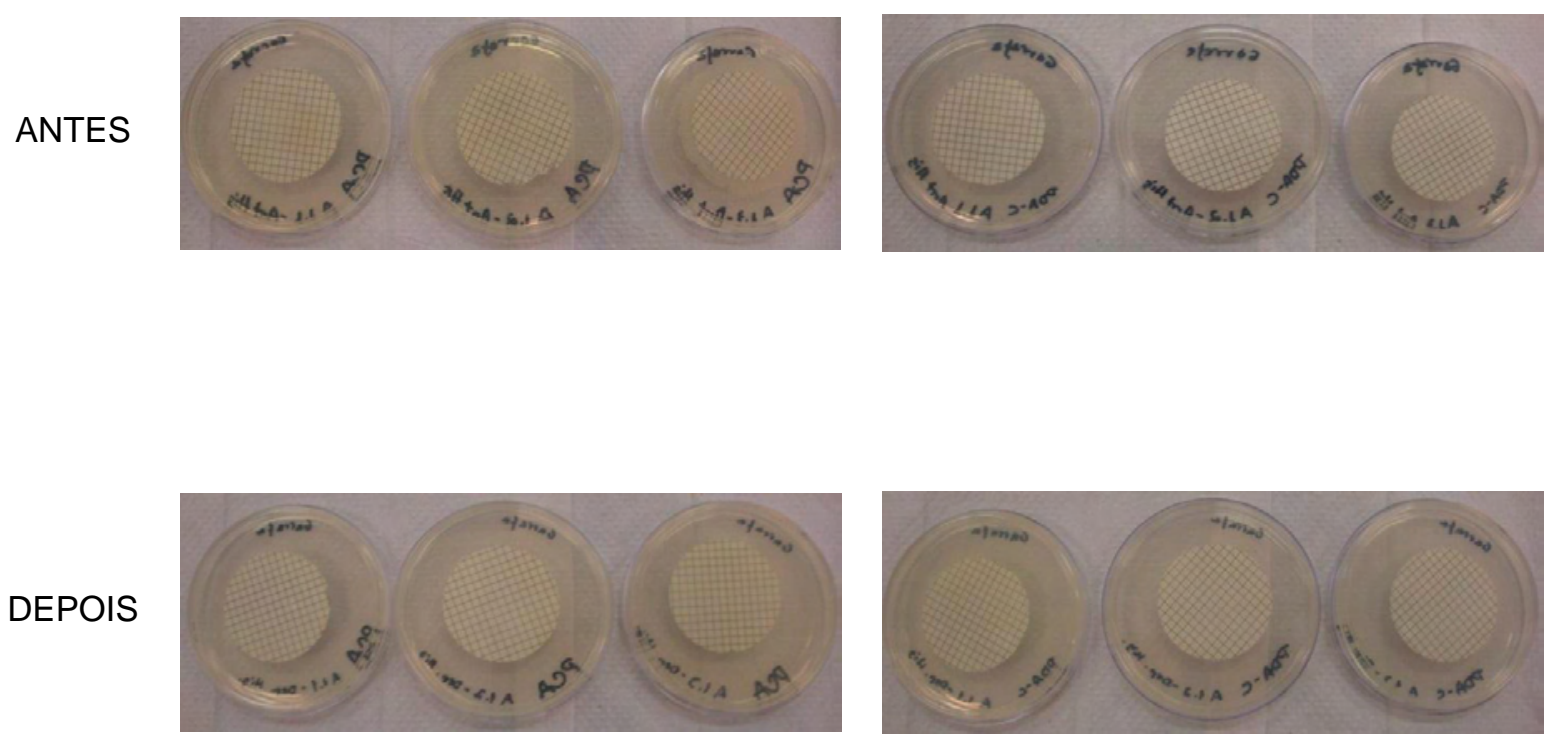

Resultados da análise microbiológica das garrafas PET antes e após a descontaminação. Placas com PCA (esquerda) e com PDA-c (direita).

ANTES
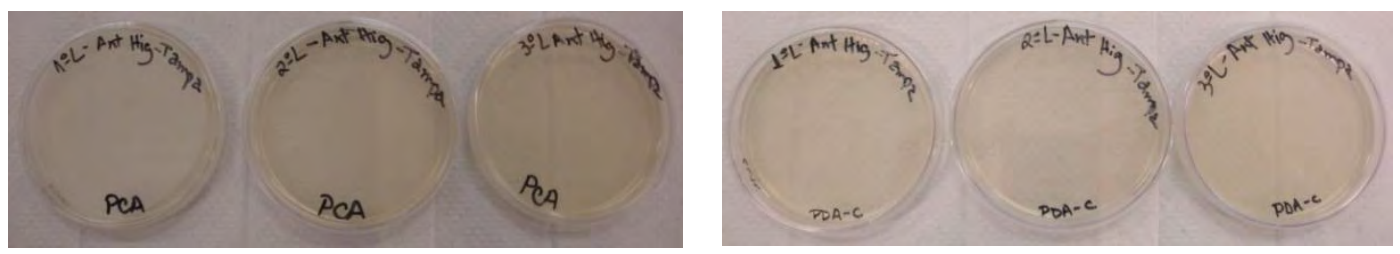

DEPOIS
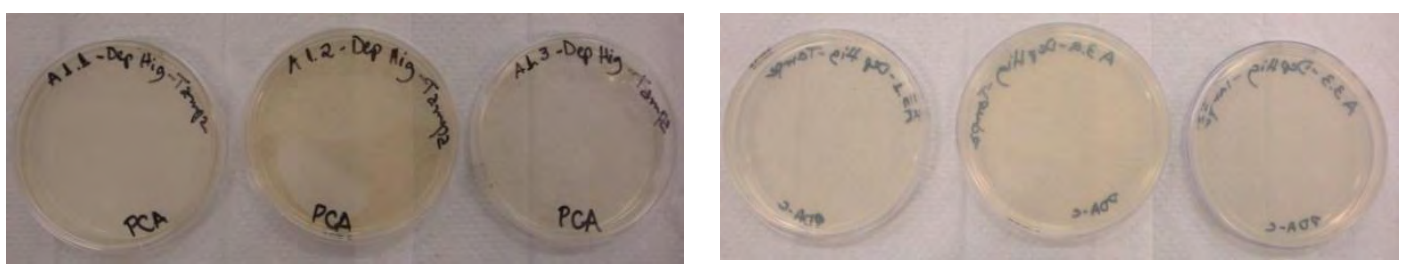

Resultados da análise microbiológica das tampas antes e após a descontaminação. Placas com PCA (esquerda) e com PDA-c (direita). 